\title{
A Network-Based View of Regional Growth
}

\section{Robert Huggins}

Centre for Economic Geography, Cardiff School of Planning and Geography, Cardiff University, Cardiff, CF10 3WA, UK.

E-mail: $\underline{\text { HugginsR@cardiff.ac.uk }}$

and

\section{Piers Thompson}

Nottingham Business School, Nottingham Trent University, Burton Street, Nottingham, NG1 4BU, UK.

E-mail: piers.thompson@ntu.ac.uk

This is a pre-copyedited, author-produced PDF of an article accepted for publication in Journal of Economic Geography following peer review.

The version of record:

Huggins, R. and Thompson, P. (2014) 'A network-based view of regional growth', Journal of Economic Geography, 14 (3), 511-545. DOI:

$10.1093 / \mathrm{jeg} / \mathrm{lbt012}$

is available online at:

http://dx.doi.org/10.1093/jeg/lbt012 


\title{
A Network-Based View of Regional Growth
}

\begin{abstract}
The need to better understand the mechanisms underlying regional growth patterns is widely recognised. This paper argues that regional growth is partly a function of the value created through inter-organisational flows of knowledge within and across regions. It is proposed that investment in calculative networks by organisations to access knowledge is a form of capital, termed network capital, which should be incorporated into regional growth models. The paper seeks to develop a framework to capture the value of network capital within these models based on the spatial configuration and the nature of the knowledge flowing through networks.
\end{abstract}

\section{Introduction}

The sources of economic growth are increasingly considered to be based on the role that the production, distribution, and use of knowledge play within and across economies (Grossman and Helpman, 1994; Harris, 2001; Ibert, 2007; Zucker et al., 2007; Vaz and Nijkamp, 2009; Antonelli et al, 2011). The knowledge-based economy is generally considered to consist of the sphere and nexus of activities and resources centered on, and geared toward, innovation (Romer, 2007). The innovation systems literature, in particular, pinpoints the flow of knowledge across organisations as a crucial factor for effective innovation (Lundvall, 1995; Freeman, 1987; 1994; Cooke, 2004; Andersson and Karlsson, 2007; Cooke et al, 2011; Harris, 2011).

Endogenous growth theory further stresses the role of knowledge as a key driver of productivity and economic growth, which departs from the traditional emphasis on the accumulation of physical capital (Aghion and Howitt, 1998; Lucas, 1988; Romer 1986, 1990). Theorists of economic development have increasingly drawn upon models of endogenous growth to better understand the factors underpinning such development. Endogenous growth theory generally assumes that economic growth is at least partly a function of stocks of knowledge in the form of human capital or the outcomes of research and development (R\&D) activities. The use of the term 'endogenous' is recognition that economic growth is influenced by the use of 'investment resources' generated by economies themselves, rather than the exogenous factors associated with traditional growth models. These early models are rooted in the work of Solow $(1956 ; 1957)$ and Swan (1956), which focused on physical capital and the supply of labour as the key sources of growth (Andersson and Karlsson, 2007).

Despite contemporary theoretical developments in the field of economic growth, Aghion and Howitt (1998) suggest that there is a need to further widen our conception of the investment resources underpinning economic growth. At the regional level, it is similarly recognised that there is a need to better understand the mechanisms underlying regional growth patterns (Andersson and Karlsson, 2007; Capello and Nijkamp, 2009; Stimson et al., 2011). Indeed, it is suggested that 
perhaps the most interesting implications of endogenous growth theory relate to the impact of the spatial organisation of regions on flows of knowledge. In particular, it is considered that differences in regional growth can potentially be explained by differences in the conditions for creating, accumulating and - crucially - transmitting knowledge (Roberts and Setterfield, 2010). For instance, it is argued that increasing returns are realised through both the geographic and organisational processes resulting from localisation, and in time the spatial and economic diffusion of knowledge (Pred and Hagerstrand 1967; Storper, 2009).

The key aim of this paper is to propose that the inter-organisational networks underpinning the flow of knowledge within and across regions are a key capital input within regional growth processes. For this purpose, inter-organisational networks are defined as consisting of the interactions and relationships that organisations utilise to access knowledge beyond the market. The term 'organisation' is principally used to refer to firms, but also the wider spectrum of relevant actors, such as universities, within regional economies. Although there is a generally accepted view that inter-organisational networks provide the means for knowledge flow, there have been few attempts to incorporate the role of such networks within regional growth models. This paper seeks to not only address this issue, but also to move away from the view of knowledge spilling-over in a one-way direction from one organisation to another, to one in which knowledge flows in multiple directions through inter-organisational networks, within which knowledge is necessarily shared and exchanged. The paper argues that the economic growth of regions is partly a function of the value created through inter-organisational flows of knowledge.

Fundamentally, the paper proposes that the concept of network capital - in the form of investments in calculative relations through which organisations gain access to knowledge to enhance expected economic returns - should be incorporated into regional growth models. The notion of network capital has been increasingly discussed and developed in the literature in recent years (e.g. Huggins, 2010; Huggins and Johnston, 2010; Kramera and Revilla Diez, 2011; Kramera et al., 2011; Lawton Smith et al., 2012), and provides a useful and necessarily specific means of conceptualising and incorporating the asset value of investments in inter-organisational networks into these growth models.

The network metaphor has become highly prevalent within the economic geography and regional economic development literature, with a vast body of work on notions such as global production networks (Olds and Thrift, 1997; Henderson et al;. 2002; Coe et al, 2004; 2008) innovative milieu (Maillat, 1998a; 1998b), regional innovation systems (Asheim and Isaksen, 2002; Cooke, 2004; Doloreux, and Parto, 2005), and clusters (Porter, 1998; Wolfe, and Gertler, 2004; Malmberg and Power, 2006; Huber, 2011), suggesting the relevance of networks to economic 
growth and performance. While these studies often apply the network concept in a broad manner, few have sought to apply it in a more formal and constrained way, which would allow for a more precise rendering of the potential role of networks within regional growth processes. Through the concept of network capital, the paper develops a more formal model that captures the value of networks within these processes.

The remainder of the paper is structured as follows: section 2 provides an outline of the key features of endogenous growth models in the context of regions. Section 3 critiques the associated literature related to knowledge spillovers and the requirement for absorptive capacity; section 4 proposes that the notion of inter-organisational networks offers an important mechanism for analysing knowledge flows within and across regions; section 5 proposes that inter-organisational networks are a form of capital - termed network capital - that help explain patterns of innovation and growth; section 6 proposes that the nature of knowledge accessed through networks will be an important factor determining the value organisations accrue from their network capital; section 7 proposes the inclusion of network capital measures within analyses of regional growth ; section 8 provides a discussion of some of the key issues relating to the proposition that regional growth is a function of the network capital stocks of respective regions; with section 9 highlighting some concluding comments and remarks.

\section{Regions and Endogenous Growth}

As indicated above, economic growth rates are increasingly considered to be dependent on endogenous factors, with most treatments commonly assuming that economic growth is partly a function of either stocks of human capital -as proposed by Lucas (1988), or R\&D - as proposed in Romer (1986) model. Romer (1986), for instance, specifies a model of long-run growth in which knowledge is assumed to be an input into production that has increasing marginal productivity.

In a more recent treatment $\mathrm{Ha}$ and Howitt (2007) propose a general model for growth based around a Cobb-Douglas production function. In equation 1 below this has been adapted to account for a regional economy. In this case, it is assumed that regional output $(Y)$ is a function of the physical capital $(K)$ and the effective labour force in the region. The effective labour force is then determined by the labour available in the region $(L)$, the human capital of the labour $(h)$, and the productivity of this labour $(A)$, which can also be considered as the level of existing knowledge within the region.

Regional output in region $r$ in period $t$ :

$$
Y_{r t}=K_{r t}^{\alpha}\left(A_{r t} h_{r t} L_{r t}\right)^{1-\alpha}
$$


Where:

$K_{r t}$ is the physical capital stock of region $r$ in period $t$

$A_{r t}$ is the level or knowledge/productivity in region $r$ in period $t$

$h_{r t}$ is the human capital stock in region $r$ in period $t$

$L_{r t}$ is the stock of labour in region $r$ in period $t$

$\alpha$ is the relative importance of physical capital in the production process

The output function is assumed to have constant returns to scale, with the growth rate of output as shown in equation 2 - being determined by the growth of the different stocks of labour, physical capital, human capital and the rate that productivity increases.

Regional growth in region $r$ in period $t$ :

$$
\frac{\dot{Y}_{r t}}{Y_{r t}}=\alpha \frac{\dot{K}_{r t}}{K_{r t}}+(1-\alpha)\left(\frac{\dot{A}_{t}}{A_{t}}+\frac{\dot{h}_{r t}}{h_{r t}}+\frac{\dot{L}_{r t}}{L_{r t}}\right)
$$

In this model, human capital is assumed to be a function of the schooling received. Given that the model is based on a regional economy, where flows of labour in and out of the economy are likely to be relatively larger than those for a nation, this model incorporates the possibility of education being obtained outside the region, rather than just from schooling (equation 3). It is possible, therefore, under the conditions envisaged by, for example, Florida (2002) that a region's policymakers may be able to influence this net flow of human capital into the region by making the region an attractive place to live.

$$
h_{r t}=e^{\theta s_{r t}+\varphi s_{q r t}}
$$

Where:

$s_{r t}$ is years of schooling originating from inside the region $(r)$

$S_{q r t}$ is years of schooling in region $r$ originating from outside the region (region $q \neq r$ )

$\theta$ is the relationship between years of schooling and human capital

$\varphi$ is the relationship between years of schooling from outside the region and human capital

In this case, human capital growth equates to:

$$
\frac{\dot{h}_{r t}}{h_{r t}}=\theta \dot{s}_{r t}+\varphi \dot{s}_{q r t}
$$

Under neoclassical growth theory, the growth rate of productivity/technological advancement/ or knowledge is assumed to be exogenous. This means that the steady state growth rate is a function of the population growth rate. However, endogenous and semi-endogenous models (which additionally also account for population change) assume that knowledge growth is determined endogenously, with growth being a function of the inputs into the knowledge creation process (equation 5). 
Knowledge/productivity growth:

$$
g_{A r} \equiv \frac{\dot{A}_{r}}{A_{r}}
$$

Ha and Howitt (2007) outline a general model that incorporates the neoclassical, first generation fully endogenous, second generation fully endogenous and semi-endogenous growth models as special cases. The general model - with equation 6 highlighting a regional treatment- allows R\&D inputs into the knowledge production process, the range of products produced, and the current level of knowledge to enter the function (although restrictions on the coefficients attached to these variables may mean they have no influence on the knowledge growth rate).

General model of knowledge/productivity growth:

$$
g_{A r}=\lambda\left(X_{r} / Q_{r}\right)^{\sigma} A_{r}^{\phi-1}
$$

In the steady state:

$$
Q \propto L^{\beta}
$$

Where:
$X_{r}$ are R\&D inputs being used in region $r$
$Q_{r}$ is the range of products being produced in region $r$
$\sigma$ is the coefficient that determines the importance of R\&D inputs
$\phi$ is the coefficient that determines the returns to scale from knowledge
$\beta$ is a coefficient representing product proliferation.

This model makes clear that endogenous growth is considered to be driven by technological change arising from intentional investment decisions made by profit-maximising agents, with the stock of human and knowledge capital - and investments in such capital - determining the rate of growth (Romer, 1990; Ha and Howitt, 2007). As valuable as these growth models are, they do not take full account of the investment firms and other organisations in regions make in accessing knowledge from other actors both in their region and beyond. In sections 3-6 a theoretical review and analysis of this potential oversight is presented along with suggestions as to potential solutions. Section 7 returns to the regional version of $\mathrm{Ha}$ and Howitt (2007) growth model to explore the incorporation of network capital as measure of the capacity and capability to access economically beneficial knowledge.

\section{Knowledge Spillovers}

Prior to the focus on endogenous modes of growth, the analysis of regional growth and long-term differences can generally be traced to the neo-classical approaches associated with Borts and Stein (1964), and more seminally Marshall (1890), which eventually led to a new emphasis on the role of 
increasing returns as proposed by Kaldor (1970) and others (Roberts and Setterfield, 2010). Knowledge in these models is usually considered to be a public good that frequently 'spills over' to other organisations, allowing others to reap where they have not necessarily sown (Acs et al, 2009). In endogenous growth models, knowledge is also considered to spillover to other organisations, resulting in the generation of increasing returns (Roberts and Setterfield, 2010). In this case, however, knowledge is not in fact considered to be a purely public good, but one that is at least partially excludable - such as through the use of intellectual rights - given that organisations often consider there to be incentives for investing in its creation. Similarly, models seeking to explain innovation outputs, such as patents, are based on a knowledge production function in which organisations (i.e. firms) intentionally pursue new economic knowledge as a means of generating innovation (Griliches, 1979; Audretsch, 2000). This pursuit is generally considered to consist of the appropriation and exploitation of the knowledge spilling over from other organisations (other firms, universities and the like).

Despite these theoretical developments, endogenous growth theorists throw little light on the mechanisms by which knowledge is transmitted across organisations (Storper and Venables, 2004), suggesting the need for a research agenda identifying the role that investments in spillover conduits make in generating economic growth (Audretsch and Feldman, 1996).

Knowledge spillovers can generally be defined as the continuum between pure knowledge spillovers that are uncharged, unintended and not mediated by any market mechanism, and rent spillovers consisting of externalities that are at least partially paid for (Andersson and Ejermo, 2005). Importantly, knowledge spillovers are increasingly conceptualised as a regional phenomenon, resulting in an enhanced focus on regions as key units through which economic growth can be best understood (Audretsch and Lehmann, 2005; Ó hUallacháin and Leslie, 2007). A seminal study by Audretsch and Feldman (1996) finds that innovative activity tends to geographically cluster more in knowledge-intensive industries where knowledge spillovers play a decisive role. Although such industries tend to exhibit a geographic concentration of production activity, clustering of their innovation activities tends to be even greater.

Whilst endogenous regional growth can be considered the desired outcome of knowledgebased development and innovation, it is argued that the process of 'endogenous development' underpins the growth trajectories of regions (Maillat, 1998a; 1998b; Garofoli, 2002; VázquezBarquero; 2007). The principles of the endogenous development school of regions are rooted in the role that factors such as collective learning and cooperative behaviour play in the establishment of an innovative milieu - or what some refer have referred to as 'technopoles' (Castells and Hall, 1994), 'industrial districts' (Capello, 1999), or 'clusters' (Porter, 1998) - facilitating knowledge flow and new 
knowledge creation. As Garofoli (2002) argues, endogenous development primarily concerns the capacity to innovate and produce 'collective intelligence' in a localised environment, which explicitly recognises the relevance of diffusing, accumulating, creating and internalising knowledge. In this sense, the region itself acts as an organisational form of coordination facilitating sustainable competitive advantage (Courlet and Soulage, 1995; Maillat, 1998a; Lawson and Lorenz, 1999; Garofoli, 2002).

The centrality of knowledge spillovers within processes of endogenous development is evident in the way through which, for example, cluster boundaries are defined (Porter, 1998). As Porter argues, 'drawing cluster boundaries is often a matter of degree, and involves a creative process informed by understanding the most important linkages and complementarities across industries and institutions to competition. The strength of these "spillovers" and their importance to productivity and innovation determine the ultimate boundaries' (Porter 1998: 202). Although it could be argued that agglomeration forces beyond technological development will also play a significant role in delineating cluster boundaries, it is clear that the extent of knowledge spillovers are also of significance in shaping these boundaries, as well as forming the basis of a cluster's overall innovativeness (Huggins and Izushi, 2011).

Clearly, a key dimension of spillovers is geographic distance, with the general argument being that knowledge spills over more easily within regions than at a distance (Jaffe et al., 1993). This suggests that local organisations may often be embedded in regional knowledge channels (Breschi and Malerba, 2001; Breschi and Lissoni, 2009; Krätke, 2010), with ready access to local public or private research institutes and universities being facilitated through local knowledge flow routes (Mueller, 2006). However, while organizations may benefit from local knowledge spillovers as an undirected and spontaneous 'buzz' (Storper and Venables, 2004), they may also need to consciously build non-local 'pipelines' to tap into knowledge from outside their region (Bathelt et al., 2004). For instance, knowledge spillovers are found to be greater in the presence of knowledge investments, and vice versa, with those regions possessing high knowledge investments experiencing a higher level of knowledge spillover - with inter-regional spillovers contributing significantly to regional knowledge production (Bathelt et al., 2004). Therefore, despite the recognised importance of spatial proximity to network development, there is an increasing emphasis on the importance of understanding networks and knowledge flows in an environment that is simultaneously local and global (Simard and West, 2006; Andersson and. Karlsson, 2007; Lorentzen, 2008; Van Geenhuizen, 2008; Maggioni and Uberti, 2009; Broekel and Boschma, 2011; Laursen et al, 2011). In particular, globalisation and technological progress are considered to spur openness in the innovation process across the globe by expanding the extent of the market, allowing for increased 
divisions of labour and providing new ways to collaborate and coordinate across geographical distances (Gassmann, 2006; Drejer and Lund Vinding, 2007; Moodysson, 2008; Crevoisier and Jeannerat 2009; Trippl et al., 2009; Dahlander and Gann, 2010).

In general, a growing base of evidence suggests that knowledge is increasingly flowing across geographic clusters, resulting in heightened global knowledge connectivity. This has led some to question the view that tacit knowledge transfer is confined to local milieus, arguing that firms source tacit knowledge from selected providers located outside the local milieu by investing in the building of new channels of communication (Wolfe and Gertler, 2004; Fontes, 2005; Gertler, and Levitte, 2005; Fitjar and Rodriguez-Pose; 2011). It is suggested, therefore, that although knowledge spillovers may take place across regions, it is usually through more selective routes (Audretsch and Feldman, 1996; Audretsch and Lehmann, 2005; Bode, 2004).

Knowledge may have the potential to spill over from one organisation to another, but knowledge access or acquisition is dependent on cumulative processes whereby 'new' incoming knowledge is utilisable only when there is the necessary complementary knowledge already in place in the receiving organisation (Döring and Schnellenbach, 2006). This is considered to require the development of absorptive capacity, defined as the ability to recognise the value of new, external knowledge, assimilate it, and apply it to commercial ends, i.e. the process of innovation (Cohen and Levinthal, 1990). Absorptive capacity is often history-dependent and reflects how much an organisation has invested in the area of expertise it specialises in, and is largely reliant upon an organisation's investment in innovation efforts (Cohen and Levinthal, 1990; Zahra and George, 2002). This indicates that accessing knowledge depends not solely on the availability of external knowledge and sources, but also on factors internal to organisations. Absorptive capacity is mediated by the wider environment in which an organisation competes and operates, with organisations that are part of economic systems and networks such clusters and innovation systems more likely to be characterised by strong absorptive capacity (Van den Bosch et al., 1999; Giuliani, 2005). This suggests that knowledge is not in fact diffused evenly 'in the air', but flows principally through a core group of organisations with advanced absorptive capacities (Giuliani and Bell, 2005; Malecki, 2010a; Ter Wal and Boschma, 2011). Therefore, as well as being an organisational-level trait, absorptive capacity also possesses regional-level characteristics, with high absorptive capacity regions having an above average proportion of organisations with advanced capacities.

\section{Inter-Organisational Networks and Knowledge Flow}

Converse to knowledge spillover models, models of cumulative causation consider knowledge to be a private good that is utilised by a clearly confined group of users (Myrdal, 1957; Döring and 
Schnellenbach, 2006). However, as Döring and Schnellenbach (2006) argue, both the knowledge spillover and cumulative causation theses can be criticised to some extent for their lack of realism. In an effort to reify an understanding of the nature of knowledge flow, and perhaps better align knowledge spillover and cumulative causation theories of growth, the role of inter-organisational networks as facilitators of knowledge flow has increasingly come to prominence across the economics, geography and management fields (Zucker et al., 2007; Tappeiner et al., 2008; Maggioni and Uberti, 2009; Bergenholtz and Waldstrøm, 2011; Colombo et al., 2011). Inter-organisational networks in this sense are defined as consisting of the interactions and relationships organisations (principally firms) utilise to access knowledge beyond their market relationships. In other words, these networks consist of the means by which knowledge flows across organisations beyond the direct purchasing of it. As others have noted, inter-organisational networks of this kind generally come into being due to markets for knowledge being rare, since - with the exception of knowledge protected by property rights, such as patents and copyrights - they are difficult to create due to inherent asymmetry in the existing knowledge base of buyers and sellers (Arrow, 1971; Grant, 1996; Maskell, 2000; Audretsch and Keilbach, 2008; Malecki, 2010a). Inter-organisational networks, therefore, are increasingly found to act as a conduit facilitating the flow of skills, expertise, technology, R\&D and the like (Andersson and Karlsson, 2007; Weterings and Ponds, 2009).

Organisations clearly utilise considerably more knowledge than that which they have themselves created (Storper, 2000), and the key reason underlying inter-organisational knowledge flows is the search for 'lacking knowledge', which is not necessarily limited by geographical boundaries or a trusted base of existing local contacts (Weterings and Ponds, 2009; Torre and Rallet, 2005). Conversely, everything is not necessarily connected to everything else (Martin and Sunley, 2007), with the evolution of networks consisting of the processes whereby new nodes connect to existing nodes (Boschma and Frenken, 2006). Cooke (2009) aptly cites Penrose's comments concerning the role of connectivity as a firm-level resource: '[T] he rapid and intricate evolution of modern technology often makes it necessary for firms in related areas around the world to be closely in touch with developments in the research and innovation of firms in many centres' (Penrose 1995, p. xix). As Cooke (2009) notes, the concept Penrose says she would have used to denote this shift had it been available in 1959, when her seminal work on 'The Theory of the Growth of the Firm' was first published, is that of knowledge networks.

Although there is a generally accepted view that networks provide the means for knowledge flow, there have been few attempts to incorporate the role of such networks within regional growth models, with the regional growth literature continuing to focus on one-way spillovers of knowledge rather than that flowing in multiple directions through inter-organisational networks. As Asheim and 
Gertler (2005) indicate, knowledge does not flow uni-directionally, but multi-directionally through networks. Organisations, therefore, utilise inter-organisational networks to manage flows and access knowledge to enhance expected economic returns. In particular, inter-organisational networks are an important aspect of the innovation process, with network scholars stressing that innovation is a complex process often requiring knowledge flow between organisations. (Meagher and Rogers, 2004, Lichtenthaler, 2005; Sammarra and Biggiero 2008). Increasingly, this process is viewed as a systemic undertaking, i.e. organisations no longer innovate in isolation but through a complex set of interactions with other organisations (Chesbrough, 2003).

It is through the networks underpinning these systemic processes that organisations access knowledge that they cannot, or do not wish to, generate internally. It is possible to distinguish two general forms of inter-organisational network: (1) contact networks, through which organisations source knowledge; and (2) alliance networks, through which organisations collaborate to innovate. Networks in the form of alliances usually concern formalised collaboration and joint ventures, and other relationships resulting in frequent and repeated interaction. Organisations gain advantages from networks by accessing the knowledge of the organisations in their network. This means that the advantage organisations are potentially able to gain is dependent upon the knowledge profile of their network (Stuart 2000; Ireland et al. 2002; Grant and Baden-Fuller 2004).

A key feature of most of the extant network literature concerning alliance networks is the focus on 'repeated' and 'enduring' (Podolny and Page 1998) or 'sustained' (Huggins, 2001) interactions or relationships. Converse to alliances, contact networks consist of non-formalised interaction and relationships between organisations. The structure of these networks is often more dynamic, as organisations continually update and change their contacts (Burt 1992; Huggins 2000, 2001; McEvily and Marcus 2005; Grabher and Ibert 2006; Trippl et al., 2009). Contact networks can be considered to be a particular form, or subset, of the type of wider contact systems facilitating the flow of resources and economic development within and across regions (Thorngren, 1970; Malecki, 1989; Anselmo de Castro and Jensen-Butler, 2003). For both alliances and contact networks, the focus of the network is on accessing, rather than acquiring, knowledge. This is consistent with the knowledge-based view of the firm, which considers inter-organisational networks as principally a means of utilising the knowledge of others, rather than necessarily seeking to internalise such knowledge within the organisation (Grant and Baden-Fuller 2004).

In general, inter-organisational networks are considered to be a crucial element underlying the economic growth and success of regions (Asheim et al. 2003; Bathelt et al. 2004; Cooke et al. 2004; Rutten and Boekema 2007; Brökel and Binder, 2007). In particular, it is argued that the existence of established spatially proximate inter-organisational networks are one of the key reasons 
why a number of the most successful regions throughout the world have become or remained more competitive, and grown faster, than those that have not adopted a networked approach (Storper 1997; Lawson and Lorenz 1999; Huggins 2000; Owen-Smith and Powell 2004; Knoben and Oerlemans 2006). It is argued that networks within these leading regional economies are able to mobilise and fully develop the knowledge residing within regional organisations through interorganisational networks, and to provide feedback loops ensuring the continuation of high levels of innovation (Bresnahan and Gambardella 2004; Crescenzi 2005; Garnsey and Lawton Smith 1998; Goman 2000). Similarly, research on agglomeration economies has indentified 'communication externalities' as an important factor that sits alongside externalities pertaining from human capital (Charlot and Duranton, 2004; 2006).

\section{Network Capital}

The aim of this section of the paper is to argue that along with the acknowledged components of growth models - such as human capital, R\&D, physical capital, and labour - the inter-organisational networks facilitating the flow of knowledge should also be considered as a key capital input or resource underpinning growth processes. It is proposed that the investment in calculative relations through which organisations gain access to knowledge to enhance expected economic returns is itself a form of capital, which can be termed network capital (Huggins, 2010; Huggins and Johnston, 2010; Kramera and Revilla Diez, 2011; Kramera et al., 2011; Lawton Smith et al., 2012).

Some scholars have pointed to networks endowed with social capital - in the form of interpersonal relationships - as a key lubricator of knowledge spillovers (Iyer et al., 2005; Tura and Harmaakorpi, 2005; Hauser et al., 2007; Lorenzen, 2007; Walter et al., 2007; Tappeiner et al., 2008; Cantner et al., 2009; Vorley et al., 2012). In its fundamental form, social capital concerns the capacity and capability of individuals to mobilise their network to enhance personal returns usually within place-bound environments. Others have utilised the allied concept of relational capital, consisting of the values of individuals operating within a particular local or regional milieu, as leading to contributions to innovation and production through social investments in trust and reciprocity within this milieu (Kale et al., 2000; Crevoisier, 2004; Capello, 2002; Capello and Faggian, 2005). Although social or relational capital may explain a degree of knowledge flow within a particular region, it does not necessarily account for the large proportion of the follow of economically beneficial knowledge (Bathelt et al, 2004; Weterings and Ponds, 2009; Huber, 2011). As Lin (2001: 17-18) argues, social capital is an "investment in social relations by individuals through which they gain access to embedded resources to enhance expected returns". In other words, social capital is a social and individually held capital. Most commonly, social capital consists of the perceived value 
inherent in individual and inter-personal networks and relationships generated through socialisation and sociability as a form of social support (Borgatti and Foster 2003).

This leaves us with the question of how to understand and analyse the relational assets held by organisations, rather than those of individuals. The network capital concept is rooted in the recognition that the leveraging of inter-organisational networks is an asset that can be shaped by organisations, and is generated by investments in calculative relations. This is significantly different from the type of social or relational capital stemming from the social norms and customs present in a particular region (Capello and Faggian, 2005; Tura and Harmaakorpi, 2005). These social norms and customs are embedded in the social environment, and the trustworthiness of any environment is often tacit and specific to each community (lyer et al., 2005; Lorenzen, 2007). However, as Putnam finds, although communities, especially business communities, are now more networked than ever, they actually possess less social capital, and 'in some ways social capital may be economically counterproductive' (Putnam, 2000, p. 322).

Network capital consists precisely of the capacity and capability of organisations (principally firms) to access knowledge from other organisations to enhance expected economic returns. Network capital, therefore, is a relational asset stemming from strategic inter-organisational networks designed specifically to facilitate knowledge flow, innovation, and to accrue economic advantage for organisations.

Networks concern investments in 'interaction capability', and as intangible capital structures should be analysed as capital objects (Westlund, 1999). As Westlund and Nilsson (2005) argue, 'when these investments are made in social networks, it is logical to say that they amass a form of 'social capital" (p. 1081). However, when organisations deliberately invest in networks, these networks are different from social networks as they concern the development of relationships which Williamson (1993) refers to as 'calculative', since they consist of actions motivated by expected economic benefits (Hite and Hesterly, 2001; Belussi and Sedita, 2011).

The notion of network capital is a response to the increased recognition that interorganisational networks can be considered a strategic resource for firms (Mowery et al., 1996; Dyer and Singh, 1998; Madhaven et al., 1998; Lorenzoni and Lipparini, 1999; Kogut, 2000; Gulati, 2007). Notably, research stemming from the field of strategic management has proposed an extension of the resource-based view of the firm to account for external network capabilities (Lavie 2006; Gulati, 1999; Gulati, 2007; Gulati and Gargiulo, 1999; Gulati, Nohria and Zaheer, 2000).

Oliver (1997) suggests that two types of rationality are at play within organisational resource selection processes: economic rationality based on systematic and deliberate decision processes oriented towards economic goals; and normative/social rationality based on habitual and 
unreflective decision processes embedded in norms and traditions. The source of network capital is rooted in an economic rationality, whereby organisations invest in establishing 'calculative' networks to access the knowledge they require. The mechanisms through which network capital are established are based on a business and economic logic, whereby access to knowledge is sought as a means of increasing economic returns. This is consistent with the view that 'profits' from social capital and social networks are not usually 'consciously pursued' by the actors within a network (Bourdieu, 1986). The distinction between different forms of network behaviour is not new, and has a long history in sociological studies. Max Weber, for instance, distinguished 'communal' (Vergemeinschaftung) relationships, based on subjective feelings, from 'associative' (Vergesellschaftung) relationships, based on rational judgments and expectations, as well as action predicated on 'custom' (Sitte) or a purely rational orientation (zweckrational) (Weber, 1968). In contrast to social networks, calculative networks provide greater resource availability (Hite and Hesterly, 2001). Network capital is likely to be highly significant to organisations as they seek to access and exploit knowledge.

While social capital is essentially a place-based social network phenomenon (Capello and Faggian, 2005; Westlund and Bolton, 2003; Rutten et al. 2010) rooted in theories of physical proximity, and dense matrices of social relations (Lorenzen, 2007), network capital is less spatially bounded in its dimensions, encompassing to a greater extent the value of networks formed in a global environment, whereby interactions are increasingly flexible, dynamic and ephemeral (Monge and Contractor, 2003). For instance, the concept of 'temporary clusters', whereby strategic network building occurs through conferences, trade fairs, exhibitions and the like, highlights the importance of network capital and access to knowledge through global pipelines (Maskell et al. 2006; Bathelt and Schuldt, 2008; 2010; Power and Jansson, 2008; Torré, 2008; Rinallo and Golfetto, 2011; Schuldt and Bathelt, 2011).

The concept of 'local buzz' (Storper and Venables, 2004), on the other hand, usually refers to the presence of social networks that are to a large extent localised and are not usually consciously established with the goal of obtaining certain knowledge, although this may occur as a by-product (Weterings and Ponds, 2009). Participating in this local buzz does not usually require particular investments, as this form of knowledge exchange is more or less automatically received by those located within a region's relevant social and economic spheres, with much of the knowledge stemming from such social networks unlikely to be economically useful (Bathelt et al, 2004; Weterings and Ponds, 2009). The notion of network capital is more attuned to capturing the role of networks as strategic evolutionary systems, with trajectories which change along with the resources they accrue (Glückler, 2007a; Kilduff and Tsai, 2003; Monge and Contractor, 2003). 


\section{The Nature of Accessed Knowledge}

This section of the paper proposes that the value of network capital is related to a number of key traits concerning the types of knowledge organisations are able to access through their interorganisational networks. In particular, it is argued that the value of network capital will be determined by the superiority, excludability, and miscibility - the capability to mix and combine different types of knowledge from different sources with their own knowledge stocks - of the knowledge they are able to access through their inter-organisational networks as a means of facilitating innovation. As indicated above, innovation is considered to be at the heart of competitive advantage attainment for both organisations and places and, as Callon (1999) argues, 'what marks innovation is the alchemy of combining heterogeneous ingredients: it is a process that crosses institutions, forging complex and unusual relations between different spheres of activity, and drawing, in turn, on interpersonal relations' (p. 2, cited in Amin and Cohendet, 2004). For organisations, this means the capability to combine and consolidate knowledge (Prahalad and Hamel, 1990).

In Schumpeterian terms (Schumpeter, 1934), innovation equates to the 'the carrying out of new combinations' relating to new goods; new methods of production; new markets; new sources of supply; or new forms of organisations. In general, innovation is facilitated by the pursuit of knowledge and its application, which is itself conditioned by the capability to 'learn-by-interacting' (Cooke, 2004). As Boschma et al (2009) argue, however, what remains unclear is how different forms of accessed knowledge contribute to the performance of organisations and regions.

Knowledge can be generally defined as information that changes something or somebody, either by becoming grounds for action or by making an organisation capable of different or more effective action (Drucker, 1989). More generally, knowledge is broadly used as a scientific notion for the most important and dynamic driver of modern economies. Unlike simple information, knowledge concerns action and is function of a particular stance (Nonaka and Takeuchi, 1995). Of course, knowledge takes many different forms, with one of the most familiar typologies suggesting that knowledge is either explicit/codified or tacit. In general, explicit knowledge refers to information that can be easily communicated and acted upon among individuals, whereas tacit knowledge - such as skills, competence, and talents - is more difficult to directly communicate to someone else in a verbal or other symbolic form (Huggins and Izushi, 2007; Nonaka and Takeuchi, 1995). More codified forms of knowledge are usually considered to be relatively less space sensitive than tacit knowledge (Bathelt et al., 2004). Reductions in transport costs and improvements in communications are considered to have increased access to codified knowledge, rendering it less 
important as a source of competitive advantage. Tacit knowledge, on the other hand, is considered not to travel well, making it a key factor underlying 'the geography of innovation' (Asheim and Gertler, 2005).

More granulated knowledge typologies include Blackler's (2002) distinction between embrained knowledge (conceptual skills and cognitive abilities), embodied knowledge (practical thinking rooted in specific contexts) (Lam, 2002; Lam and Lundvall, 2006), encultured knowledge (meanings and shared understandings resulting from socialization), embedded knowledge (systemic routines), and encoded knowledge (signs and symbols). These forms highlight the potential problems in accessing knowledge due to its intangible, non-standardized, and inseparable nature (Howells, 2012).

According to Antonelli (2008), the first major shift in the economics of knowledge occurs when the notion of knowledge as a public good is challenged, and knowledge becomes regarded more as a quasi-private good with higher levels of natural appropriability and exclusivity. Knowledge is now usually viewed as a collective process characterised not only by partial appropriability and shared property rights, but also by the role of the intentional effort, participation and contribution of interactive agents (Antonelli, 2008). In this line, Audretsch and Lehmann (2005) refer to the knowledge filter, which is the gap between new knowledge and that which Arrow (1962) refers to as economic knowledge or commercialisable knowledge. This knowledge requires intentional and often complex efforts to access and assimilate. Indeed, knowledge, but especially combinatorial knowledge, underlies the complexity of economic systems (Jensen et al., 2007; Martin and Sunley, 2007; Mattes, 2011).

The notion of combining knowledge through miscible flows - i.e. the extent to which different types and forms of knowledge can be combined and mixed to create value - is similar to Romer's (1996) idea of creating new recipes from existing knowledge. As Storper and Scott (2009) argue "knowledge has a tendency to grow indefinitely, for it can be endlessly re-used, is extremely leaky (and hence its circle of users continually expands), and can be combined and recombined in virtually unlimited ways.' (p. 148). In this sense, value is created when there is a 'collision' of knowledge. Network actors receive a greater proportion of the value created the 'nearer' - in a cognitive sense (Boschma, 2005) - they are to the collision.

The successful recombining of existing knowledge in novel ways through networks (Nelson and Winter, 1982) involving knowledge 'collisions' and 'transpositions' (Powell and Grodal, 2005) is an example of the effective miscibility of knowledge. Similarly, combining different fields of knowledge creation, such as technology fusion (Kodama, 1992), represents effective knowledge miscibility (Cantwell, 2005). According to Quatraro (2010), knowledge is the outcome of a 
combinatorial search activity carried out across a technological space in which combinable elements reside. In this sense, miscibility will be based upon rates of knowledge coherence and variety (Frenken et al., 2007; Boschma et al, 2009; Quatraro, 2010). In many ways, the notion of the miscibility of knowledge harks back to Schumpeter's (1934) insight that innovation results from the carrying out of new combinations. Similarly, it underlines the role of networks as the catalysts of the type of institutional layering, conversion, and recombination of knowledge that Martin (2000) argues are key features of the dynamic processes of path dependence.

The excludability of knowledge will be compromised if it is allowed to 'leak' outside a particular network. 'Sticky' knowledge is considered to be that which is difficult to move, while leaky knowledge refers to the undesirable flow of knowledge to external sources (von Hippel, 1994; 1998; Brown and Duguid, 2001). Without effective network management knowledge may leak more freely out of a network than productively within it (Teece, 1998, Fleming et al. 2007). Effective network management, through strategic and intentional investment in relationships, i.e. network capital building, is a mechanism for ensuring that value is captured rather than lost through interorganisational networks (Lichtenthaler, 2005; Teece, 1998). Similarly, the superiority of knowledge may be compromised as organisations within a network become increasingly familiar with each other's knowledge, and negative network effects may emerge, locking organisations into low value and unproductive networks, and stifling the creation of new knowledge and innovation (Arthur 1989; Adler and Kwon 2002; Labianca and Brass 2006; Molina-Morales and Martínez-Fernández, 2009). In order to continue to play a role in the innovation process, networks are often required to evolve to include new members and configurations to meet changing needs, expanding the network capital of engaged organisations (Hite and Hesterly 2001, Lechner and Dowling 2003).

In general, the search for superior knowledge means there is an increasing focus on the dynamic nature of networks and their changeability, heightening the importance of indirect ties and the need for the on-going reconfiguration of networks (Gargiulo and Benassi 2000; McFadyen and Cannella 2004; Levine 2005; Bathelt and Turi, 2011). As Gulati (1999) argues, networks are dynamic and change over time, which suggests that networks require diversity in the types of investments made. Unless diversity is sustained, in the long-run networks may reduce heterogeneity through the articulation of shared norms, standards, and rules of conduct among organisations (Oliver 1997; Monge and Contractor 2003). Although stable networks may reduce the potential costs of network capital, it is likely that as knowledge becomes increasingly homogeneous and less useful across network actors, the value of network capital may well erode (Maurer and Ebers, 2006). Network capital investments may become ineffective if there is knowledge equivalence between organisations due to similarities in knowledge profiles, which results in network redundancy (Cowan 
et al., 2004). These inertial network forces highlight the issue of over-embeddedness, whereby the actors an organisation is best connected to may not be best placed to provide solutions to current problems (Krackhardt, 1994; Monge and Contractor, 2003; Maurer and Ebers, 2006).

\section{Network Capital and Regional Growth}

In the preceding sections the key theoretical arguments underlying the concept of network capital have been articulated. This section now explores how network capital can be more formally employed within regional growth models, based on the theoretical insights presented above.

Returning the regionalised version of Ha and Howitt's (2007) general growth model outlined in section 2; in this model it is assumed that R\&D inputs take the form of labour employed in research occupations alone. Based on the propositions raised above, however, it is suggested that network capital also plays a role in acting as a key component in terms of the R\&D-related inputs. If constant returns to scale are assumed, additional inputs acquired from network capital can only be fully utilised where additional R\&D labour is employed. In other words, increasing either R\&D staffing levels or network capital alone will have diminishing returns.

Therefore, R\&D inputs in region $r$ can be represented as follows:

$$
X_{r}=\left(v_{X r} L_{r}\right)^{\psi} W_{r}^{(1-\psi)}
$$

Where:

$v_{x r}$ is the proportion of the labour force of region $r$ employed in science and technology research activities.

$W_{r}$ is network capital stock in region $r$

$\psi$ represents the relative importance of R\&D labour as an R\&D input

In order to further model the role of network capital it can be assumed that it can be categorised into two broad forms: (1) networks associated with connections within the local region $r$; and (2) networks associated with non-local connections. The unit of local and non-local network capital is assumed to be the same since it is determined by the connections and value to organisations with region $r$. This means that in both cases it is measured in terms of total value to organisations in the region, rather than some objective measure which needs scaling by source. It is also assumed that network capital takes an additive form (equation 8). There is a case for total network capital being determined by a multiplicative relationship between network capital sources, where different types of knowledge might be complementary (Bathelt et al., 2004; Andersson and. Karlsson 2007; Lorentzen 2008; Van Geenhuizen 2008), but there is no reason to assume that this is the case for all regions.

Total network capital:

$$
W_{r}=W_{L, r}+W_{N L, r}
$$

Where: 
$W_{L, r}$ is local network capital (connections within region $r$ )

$W_{N L, r}$ is non-local network capital (connections with organisations in region $q \neq r$ )

Local network capital is assumed to be a function of the connections of organisations within region $r$ and the value of such connections to these organisations. Keller (2002) develops a similar model where intermediate goods act as the mechanism that transfers knowledge from one country (region) to another. The wider the range of intermediate goods utilized, the greater is the rate of productivity growth. Connections are not just limited to the use of other organisations' goods as inputs, although this would represent one form of connection. The number of connections formed within the region purposefully allows double counting as it is assumed that knowledge flows in both directions so that both organisations involved in the connection benefit in terms of the network capital available.

For any individual organisation there may be increasing returns from connections $(\gamma>1)$, where complementarities between knowledge sources result in each additional connection having greater importance. However, it is more likely that the redundancy of knowledge will actually lead to diminishing returns for individual organisations $(\gamma<1$ ) (McFadyen and Cannella, 2004; Goerzen and Beamish, 2005). However, as a form of regional system there may also be increasing returns from connections $(v>1)$, where the region as a whole performs more strongly as knowledge circulates at a faster rate, allowing the faster diffusion of innovation (Breschi and Lissoni, 2001). It is possible that individual organisations may suffer from knowledge redundancy, whilst the region as a whole benefits, so many well-connected organisations may generate more network capital compared to a few very well connected organisations.

The overall value of local network capital can be measured based on the average value of each single connection, which is likely to be dependent on what other connections are present within the region (equation 9):

$$
W_{L, r}=\bar{V}_{L r}\left[\sum_{i=0}^{I} C_{L r i}^{\gamma}\right]^{v}
$$

Where:

\footnotetext{
$C_{L r i}$ are the local connections of organisation $i$ in region $r$

$\bar{V}_{L r}$ is the average value of local connections in region $r$

$\gamma$ is a coefficient representing any returns to scale experienced by organisations from multiple connections.

$v$ is a coefficient representing any returns to scale experienced by the region as connectivity increases.
}

Based on the propositions outlined in section 6, the average value of the connections is assumed to be a function of the average superiority, excludability, and miscibility of the accessed knowledge. It is also assumed that the current level of human capital affects the average value of connections, based on those studies that have noted the importance of absorptive capacity in benefiting from 
network connections (Cohen and Levinthal, 1990; Van den Bosch et al., 1999; Giuliani, 2005; Crescenzi, 2005). In other words, value is determined by the capability to use accessed knowledge, rather than it being based on its compatibility with existing knowledge. If the latter were the case, the current level of knowledge, rather than human capital, would be the relevant variable. The value function does not necessarily exhibit constant returns to scale; in fact this is unlikely given the work on the resource-based view of the firm (Barney, 1991), which argues that resources are required to have multiple characteristics if they are to provide value for the firm.

In the case of local connections, their value consists of:

$$
\bar{V}_{L r}=h_{r} \bar{V}_{L s, r}^{\delta} \bar{V}_{L e, r}^{\xi} \bar{V}_{L m, r}^{\tau}
$$

Where:

$\bar{V}_{L s, r}$ is the superiority of the knowledge associated with the local connections.

$\bar{V}_{L e, r}$ is the excludability of the knowledge associated with the local connections.

$\bar{V}_{L m, r}$ is the miscibility of the knowledge associated with the local connections.

With $\delta, \xi$ and $\tau$ reflecting the relative importance of the superiority, excludability and miscibility of knowledge in determining the overall value of connections. Where $\delta+\xi+\tau>1$ would give increasing returns.

Non-local network capital will be formed in the same manner. The main difference is that connections will not be double counted, as connections will be only counted from region $r$ 's organisations and not the non-local organisations with which they are connected.

Non-local network capital:

$$
W_{N L, r}=\bar{V}_{N L r}\left[\sum_{i=0}^{I} C_{N L r i}^{\gamma}\right]^{v}
$$

Where:

$C_{N L r i}$ are the non-local connections of organisation $i$ in region $r$

$\bar{V}_{N L r}$ is the average value of non-local connections in region $r$

Value of non-local network connections

$$
\bar{V}_{N L r}=h_{r} \bar{V}_{N L s, r}^{\delta} \bar{V}_{N L e, r}^{\xi} \bar{V}_{N L m, r}^{\tau}
$$

Where:

$\bar{V}_{N L s, r}$ is the superiority of the knowledge associated with the non-local connections.

$\bar{V}_{N L e, r}$ is the excludability of the knowledge associated with the non-local connections.

$\bar{V}_{N L m, r}$ is the miscibility of the knowledge associated with the non-local connections.

In this form the formation of connections is costless. Therefore, any region would encourage organisations to generate as many connections as possible. This would increase the output of 
knowledge resources and increase the steady state growth rate. The only limit would be the number of connections that could be formed. A more realistic assumption is that forming/maintaining connections requires resources in the form of foregone production (Grabher, 2001; Bathelt et al., 2004). This cost of connection maintenance would be expected to display increasing costs of production:

$$
C_{i t}=\alpha_{0}+\alpha_{1} Z_{i t}+\alpha_{2} Z_{i t}^{2}
$$

Where

$Z_{i t}$ is organisation i's output that is foregone to maintain connections.

This foregone output may be measured in terms of the proportion of labour in the region dedicated to these activities. If it is assumed that the same proportion of labour is foregone in maintaining connections within each organisation, and there are constant returns from connections both at the organisational and regional level $(\gamma=v=1)$, the R\&D inputs equation becomes:

$$
X_{r}=\left(v_{X r} L_{r}\right)^{\psi}\left(\bar{V}_{L r} v_{L C r} L_{r}+\bar{V}_{N L r} v_{N L C r} L_{r}\right)^{1-\psi}
$$

Where

$V_{L C r}$ is the proportion of region $r$ 's labour dedicated to maintaining local network connections.

$v_{N L C r}$ is the proportion of region $r$ 's labour dedicated to maintaining non-local network connections.

This means that the implications are the same as those laid out by $\mathrm{Ha}$ and Howitt (2007). If the appropriate model is that of semi-endogenous growth (which takes account of population change) the proportion of labour dedicated to R\&D inputs will only have temporary effects. However, if the Schumpeterian second generation fully endogenous model of growth is appropriate, the long run growth rate will be influenced by the proportion of labour dedicated to R\&D inputs, either in terms of employment within science and technology activities or in terms of maintaining connections. The most appropriate division of labour will be determined by the value of network connections locally and non-locally compared to direct inputs.

\section{Discussion}

The above section has sought to provide some insights as to how network capital can be formally incorporated into future analyses of regional growth. The following section discusses some of the implications of a network capital perspective on regional growth for regional development theory more generally.

As network capital is an asset that is co-owned across the organisations involved in particular networks - with knowledge flowing in multiple directions across the organisations - it is clear that the location of these organisations will influence the output regions accrue from these 
networks. For instance, if all the knowledge flowing through a network consists of organisations based in the same region, it is likely that all the benefits will accrue to this region. If some organisations are based in another region, it is likely that some of the benefits of this knowledge flow will also accrue to this other region. Therefore, it may well be the case that the knowledge flowing from organisations in this other region is more economically valuable (in terms of its superiority, excludability, or miscibility) than that available in the focus region, with the advantages in terms of the nature of the knowledge outweighing the disadvantages in terms of organisational location.

To an extent, network capital has some resonance with the concepts of network externalities (Katz and Shapiro, 1985; Yeung, 2000; Glückler, 2007b; Martin, 2010), whereby greater access to flows of knowledge through networks increases the economic value of these networks, whilst also recognising that the value accrued will be related to the nature of the knowledge accessed. From the perspective of economic literature, network capital also chimes with endogenous growth theory's focus on the role of investment in intangible assets (Lucas, 1988; Romer, 1986, 1990; Ha and Howitt, 2007). From the perspective of the economic geography and development literature, a network capital perspective suggests that processes of endogenous development are in fact much more porous across regional boundaries, similar to the acknowledgement that agglomeration forces are never entirely locally bounded (Phelps, 1992). In particular, geographic clustering and industrial agglomeration theory is increasingly encompassing more diffuse forms of agglomeration, especially with regard to the type and geographic scale at which external economies become manifest, and the extent to which these are shared across regions and localities (Phelps and Ozawa, 2003; Phelps, 2004; Malmberg and Maskell, 2006).

In terms of the defining features of knowledge, with the exception of the most economically leading regions across the globe, it is likely that the most superior and excludable knowledge will be accessed from outside a region, while the most miscible knowledge is more likely to be contained within the region (Weterings and Ponds, 2009; Huggins et al., 2010; Belussi and Sedita, 2011). Increasing evidence suggests that many organisations do not acquire their knowledge from within regionally proximate areas, particularly those based upon innovation-driven growth where knowledge is primarily sourced internationally (Davenport 2005). Furthermore, it is considered that the constraining effect of distance on knowledge flow and transfer is gradually diminishing (Johnson et al., 2006; Tracey and Clark 2003). This knowledge is often necessarily superior to that available locally, resulting in improved performance.

As Singh (2005) finds, simply being in the same locality is often of little benefit for diffusing knowledge from creators to other actors in a locality, with there being a need for networked 
interaction between these actors. Similarly, Watts et al. (2003) find that many firms in close proximity do not necessarily share face-to-face interactions through either social or business contacts, reducing the scope for knowledge transfer. Even in those locations possessing a knowledge rich environment there is evidence of a greater role being played by non-localised networks (Athreye, 2004; Bathelt et al., 2004; Doloreux, 2004; Garnsey and Heffernan, 2005; Saxenian, 2005; Simmie, 2004; Broekel and Boschma, 2011). This suggests that propinquity is not enough, with recent empirical evidence finding that high innovation and growing firms source knowledge more frequently, especially from overseas locations, and are more likely themselves to act as a source of knowledge for overseas companies (Huggins et al., 2010).

As Boschma and Ter Wal (2007) assert, innovation is not a matter of being in the right place, but more about being a member of the right network, with too much reliance on local knowledge networks and sources being potentially harmful for innovation. Weterings and Ponds (2009) find that long-term contacts are not necessarily helpful in overcoming the uncertainty of more distant knowledge flows, nor are they more likely to be established within a region despite the higher frequency of face-to-face inter-organisational interactions. They also find significant differences in the characteristics of regional and non-regional inter-organisational knowledge flows, and whilst regional knowledge flows are characterised by a higher number of face-to-face contacts, knowledge exchanged through non-regional knowledge flows is found to be more valuable (Weterings and Ponds, 2009). Indeed, there is a growing school of thought that non-proximate actors are often equally, if not better, able to transfer complex knowledge across such spatial boundaries, providing a high-performing network structure is in place (Davenport 2005; Dunning 2000; Lissoni 2001; McEvily and Zaheer 1999; Palazzo 2005; Zaheer and Bell 2005).

This indicates that the types of inter-organisational network existing across regions, and the nature of the knowledge flowing through these networks, will impact on levels of regional growth. Therefore, the growth of a region cannot be modelled in isolation, but must be considered in relation to the networks existing across regions. At a regional level, localised flows of knowledge may result in a higher proportion of the output distributed across networks being captured and retained within a particular region i.e. by local organisations. However, limitations in the appropriateness of knowledge accessible through localised pools means that access to appropriate knowledge may be inversely related to the geographical proximity of appropriate knowledge sources.

Figures 1 and 2 present some illustrative scenarios of inter-organisational network connections for four regions $(A, B, C$, and $D)$, measured by the density (number of network connections per organisation) and the value of the networks connections to organisations. Figure 1 only shows network connections within the four regions, with Region A having both the highest 
density of network connections, and the largest number of network connections that are of high value. Conversely, Region $D$ has the lowest density of network connections, and the least number of network connections of high value. Under this scenario, therefore, Region $A$ has the largest endowment of network capital, with the opposite being true for Region $D$.

Of course, organisations in each region may also possess network connections with organisations in other regions. In Figure 2 illustrative inter-regional network connections have been added onto the intra-regional network connections shown in Figure 1. Under this scenario - i.e. taking both intra- and inter-regional network connections together - Region $D$ has the highest density of connections, and Region $A$ the least. Also, based on the assumption that the value accrued from inter-regional networks connections is equally shared by organisations in each respective region, Region $D$ has the largest number of high value network connections, and Region $A$ the least. Therefore, taking intra-regional - local network capital - and inter-regional network connections global network capital - together, Region D possesses the highest level of overall network capital. The inter-regional connections shown in Figure 2 highlight the potential network interdependency that can exist across regions. This suggests that regions with many shared inter-regional connections, such as those that are spatially adjacent, may evolve with growth rates that are relatively aligned due to the value each accrues through their shared network capital.

Figures 1 and 2 About Here

As indicated above, even organisations located in globally-leading clusters of knowledge are increasingly accessing knowledge through more global communities, rather than rely on their home base. New patterns of knowledge sourcing serve to illustrate the notion of an economic geography that is as spiky as it is flat (Florida, 2005; Friedman, 2005; Huggins, 2008). This spikiness is typified by the existence of key and leading concentrations of knowledge-based economic activity within a limited number of regional locations (Hoekman et al., 2009). These regions, however, are increasingly connected through the networks resulting from the internationalisation of markets and the broadened scope of knowledge networking activities. According to Malmberg and Power (2006) 'knowledge in clusters is seldom created through local inter-organizational collaborative interaction....in a localized cluster the majority of firms tend to have most of their important suppliers and customers somewhere else and innovation and knowledge creation tend to follow value chains that are most often global'. Contrary to Porter (1990), if the local market does not have the most sophisticated customers, firms are required to look for them elsewhere. Von Hippel (2005) highlights how markets and user-led innovation in a number of industries, such as design, are becoming increasingly international in scope. 
As Rodríguez-Pose and Crescenzi (2008) indicate, knowledge will spill over beyond regional borders as a consequence of the existence of different forms of inter-regional contacts, with flows of inter-regional knowledge acting as important agents of innovation. They further find that accessibility to extra-regional innovation is positively associated with regional growth performance, with the 'amount of knowledge' available in a region reinforcing the effect of local innovative activities (Rodríguez-Pose and Crescenzi, 2008). Similar results are produced by Badinger and Tondl (2002), who find that an inflow of knowledge has a positive impact on the growth of a region, with this effect having a larger magnitude if neighbouring regions also exhibit high growth rates. Also, Andersson and Karlsson's (2007) analysis finds that differences in regional growth rates can be explained by differences in knowledge accessibility within and across regions.

Importantly, inter-organisational networks are not formulated within a social and personal vacuum, but are based on factors such as the migration and mobility patterns of individuals (Agrawal et al., 2006). Saxenian (2006: 6) describes the role of what she terms the 'new argonauts' - or global entrepreneurs connecting advanced and developing economies, which 'are undermining the old pattern of one-way flows of technology and capital from the core to the periphery, creating far more complex and decentralized two-way flows of skill, capital, technology', resulting in the rapid development of cross-regional connections and communities. The key aspect of these developments is that the knowledge base of the world's most advanced regional economies is no longer necessarily local, but positioned within global knowledge networks, connecting clusters and their actors (Wolfe and Gertler, 2004; Huggins and Izushi, 2007; Lundquist and Trippl, 2011).

This shift towards the requirement to increasingly access knowledge from the global base represents both opportunities and challenges for regions that have traditionally possessed relatively sparse local knowledge bases. If applicable knowledge is available locally, organisations may attempt to source and acquire it; if it is perceived as unavailable, they will look elsewhere (Kingsley and Malecki 2004). Also, while organisations with low levels of absorptive capacity (Cohen and Levinthal 1990) tend to network locally, those with higher absorptive capacity are often more connected to global networks (Drejer and Lund Vinding 2007). This is perhaps to be expected, and illustrates the importance of internal knowledge absorption capacity on external knowledge network development. It also helps explain why organisations with relatively low knowledge absorption capacities tend to be reliant on more localised networks, and why non-local knowledge flows may alleviate processes of lock-in (Asheim and Isaksen, 2002; Weterings and Ponds, 2009).

In essence, the growth of regions will result from the balance between their stocks of both local and global (i.e. non-local) network capital. However, as illustrated by Figure 3, regions may achieve different growth trajectories through different forms of network capital investment. For 
instance, in the top left quadrant high growth may be achieved through high levels of investment in local network capital, manifested by a high density of regional inter-organisational networks with high stocks of valuable knowledge. This approach resembles that commonly associated in the past with regions such as Silicon Valley, Route 128, and the Italian industrial districts (Saxenian, 1994; Benner, 2003; Bresnahan and Gambardella, 2004; Mancinelli and Mazzanti, 2009). An alternative growth approach is one based on high levels of investment in global network capital (bottom left quadrant), through investments in high value cross regional inter-organisational networks. As suggested above, more contemporary evidence of successful high growth regions indicates that many are fostering heightened endowments of global network capital in tandem with strong existing stocks of local network capital. Weaker low growth regions are likely to possess poor endowments of network capital, be it of a local or global nature, as shown by the right hand quadrants of Figure 3 .

Figure 3 About Here

Fundamentally, a key driver of regional growth consists of the capability of organisations in a region to access and subsequently utilise appropriate economically beneficial knowledge. According to Storper (1997), 'the status of the region is now not merely as a locus of true externalities, but - for the lucky regions - as a site of important stocks of relational assets'. In this sense, network capital can be considered a key form of relational asset that distinguishes Storper's (1997) 'lucky' from 'unlucky' regions, as well are forming part of the territorial capital of regions, which includes not only relational assets but the wider set of natural, human, and organisational assets underpinning regional competitiveness (Camagni and Capello, 2010; Capello et al., 2011; Camagni and Capello, 2012).

Finally, it Interesting to note that there is some empirical evidence at a national level which suggests that Romer-type endogenous models do not conform very with well with actual growth rates, mainly due to the assumption that $R \& D$ actors in an economy share the whole stock of its knowledge (Huggins and Izushi, 2007). If network capital were to enter the equation it may provide more exactness in measuring the extent to which knowledge is actually shared.

\section{Conclusion}

The overall conclusion of the paper is that regional growth is partly a function of the network capital stocks of respective regions. This network capital is determined by the nature of the interorganisational networks within and across regions, and the nature of the knowledge accessed through these networks. Theories of regional development based on endogenous development, agglomeration, clusters, and innovation systems implicitly suggest that organisations located in successful regions utilise their network capital as a means of ensuring economic success. High 
growth regions will possess organisations with high stocks of network capital allowing them to access the most economically beneficial knowledge. Organisations in less successful regions are more likely to have a dearth of network capital, resulting in knowledge access capabilities being restricted to the sourcing of relatively inferior knowledge, manifested by relatively inferior growth rates for the regions in which these organisations are located.

Although network capital can be of either a local or global nature, depending on the spatial scope of networks, there may be some interdependency between the two given that successful connectivity in global spaces is often the outcome of an initial system of localised interaction, whereby it is the knowledge crossing hallways and streets that initially catalyzes intellectual exchange and knowledge transfer across oceans and continents (Glaeser et al, 1992). However, unless local networks keep abreast of knowledge emerging outside of their respective region, they run the risk of becoming rigid and outdated (Camagni, 1991; Izushi, 1997; Bathelt et al., 2004). Indeed, most regions are unlikely to be self-contained organisational communities possessing all the knowledge they require to innovate and penetrate new markets.

The notion of network capital is an attempt to capture the importance scholars have given to the relational assets approach to explaining regional development, whereby such development is theorised to be significantly embedded in local and global networks (Bathelt and Glückler, 2003; Yeung, 2005; Lorentzen, 2008). In this sense, Storper's (1997) 'holy trinity' of relational assets technology, organisations and territories - can be adapted to knowledge, inter-organisational networks, and regions. Principally, it is argued that knowledge is at the heart of achieving sustainable regional growth and, as Quatraro (2010) suggests, the creation of new knowledge brings about new variety within the economic system, which provides the basis for 'restless economic growth' through recombinant knowledge approaches to innovation. Similarly, there is growing evidence that inter-organisational networks are related to the innovation capabilities and growth of firms (Freel, 2000; Davenport, 2005; Knoben and Oerlemans, 2006; Knoben, 2009), with further evidence showing that the innovation performance of firms is significantly related to network capital investment in dynamically configured networks (Huggins et al., 2012).

From a policy perspective, a key challenge for regions is to build their stock of network capital, ensuring an appropriate balance between more local and global stocks. As Nooteboom (1999) argues, public policy should not necessarily be oriented towards particular firms or other organisations, but to enabling linkages between them. Policy interventions targeted at the development of network capital have generally been found to be more effective in core and leading regions, which is unsurprising given that they are likely to already possess higher stocks upon which to build (Huggins, 1998; 2000). Therefore, regional economic development policy in lower growth 
regions must become better attuned to supporting organisations in enhancing their network capital. Such regions should seek to establish high functioning inter-organisational networks through which they are able to access appropriate knowledge. As Antonelli (2008) states, the structure of networks affects the flow and availability of knowledge, which in turns affects the value generated by networks.

A key issue often overlooked in the relevant literature, especially policy-based literature, is the nature of the knowledge sourced by organisations and their ability to assimilate this knowledge. For instance, if organisations within a region are unable to assimilate knowledge from their internal base with that accessible from other organisations, there is a potential role for intervention in the form of policies that act as an 'emulsifier', allowing different types of knowledge to be more effectively combined.

From both a public policy and organisational management perspective, it is important to note that whilst the underlying premise of a network-based perspective on regional growth relates to the potential benefits of inter-organisational networks, there is the possibility of negative impacts. Most crucially the possibility that regions or organisations leak more knowledge from their networks than they actually gain, suggesting the need for 'spillover control' to manage unwanted leakage (Nooteboom, 1999). This further indicates the need for a greater understanding of the role of 'trade-offs' relating to the perceived value of the inward and outward flows of knowledge through networks (Allen, 1984; Brass et al., 2004).

More generally, there is a need for further evidence on the costs of investing in, and sustaining, network capital. Clearly, knowledge does not flow rapidly and costlessly around the globe (Grossman and Helpman, 1994) and, as Malecki (2010b) argues, the globalisation of knowledge has added costs as organisations communicate across national, cultural, and linguistic boundaries. Therefore, the costs of establishing and sustaining inter-organisational knowledge flows are likely to rise with geographical distance, resulting in the requirement for different forms and levels of network capital investment (Weterings and Ponds, 2009).

\section{Acknowledgements}

The authors are grateful to the Economic and Social Research Council (ESRC) (Grant Award Reference RES-171-25-0023) for partly funding the research upon which this paper is based. They are also grateful to Hiro Izushi, Andrew Johnston, Daniel Prokop, David Brooksbank and three anonymous reviewers for their comments on earlier versions of the paper. The usual disclaimers apply.

\section{References}

Acs, Z.J., Braunerhjelm, P., Audretsch, D.B. and Carlsson, B. (2009) The knowledge spillover theory of entrepreneurship, Small Business Economics, 32: 15-30. 
Adler, P.S. and Kwon, S.W. (2002) Social capital: prospects for a new concept, Academy of Management Review, 27: 17-40.

Aghion, P. and P. Howitt. (1998) Endogenous Growth Theory. Cambridge, MA: MIT Press.

Agrawal, A., Cockburn, I. and McHale, J. (2006) Gone but not forgotten: knowledge flows, labor mobility, and enduring social relationships, Journal of Economic Geography, 6: 571-591.

Allen, T.J. (1984) Managing the Flow of Technology: Technology Transfer and the Dissemination of Technological Information within the R\&D Organization, Cambridge, MA: MIT Press.

Amin, A. and Cohendet, P. (2004) Architectures of Knowledge: Firms, Capabilities, and Communities, Oxford: Oxford University Press.

Andersson M. and Ejermo O. (2005) How does accessibility to knowledge sources affect the innovativeness of corporations? Evidence from Sweden, Annals of Regional Science, 39: 741765.

Andersson, M. and Karlsson, C. (2007) Knowledge in regional economic growth: the role of knowledge accessibility, Industry and Innovation, 14: 129-149.

Anselmo de Castro, E. and Jensen-Butler, C. (2003) Demand for information and communication technology-based services and regional economic development, Papers in Regional Science, 82 (1): 27-50.

Antonelli, C. (2008) Localised Technological Change: Towards the Economics of Complexity, London: Routledge.

Antonelli, C., Patrucco, P. and Quatraro, A. (2011) Productivity growth and pecuniary knowledge externalities: An empirical analysis of agglomeration economies in European regions, Economic Geography, 87: 23-50.

Arrow, K.J. (1962) Economic welfare and the allocation of resources for invention. In: Nelson, R. (Ed.), The Rate and Direction of Inventive Activity. Princeton: Princeton University Press.

Arrow, K.J. (1971) Essays in the Theory of Risk-Bearing. Amsterdam: North-Holland.

Arthur, B. (1989) Competing technologies and lock-in by historical events: The dynamics of allocation under increasing returns, Economic Journal, 99 (394): 116-131.

Asheim, B. and Gertler M. (2005) The geography of innovation: Regional innovation systems. In The Oxford Handbook of Innovation, Fagerberg J, Mowery DC, Nelson RR (eds). Oxford: Oxford University Press.

Asheim, B. T. and Isaksen, A. (2002) Regional innovation systems. The integration of local "sticky" and global "ubiquitous" knowledge, Journal of Technology Transfer, 27: 77-86.

Asheim, B. Isaksen, A. Nauwelaers, C. and Tödtling, F. (eds.) (2003) Regional Innovation Policy for Small-Medium Enterprises. London: Edward Elgar.

Athreye, S. (2004) Agglomeration and growth: A study of the Cambridge hi-tech cluster. In T. Bresnahan and A. Gambardella (eds.), Building high-tech clusters Silicon Valley and beyond, Cambridge \& New York: Cambridge University Press.

Audretsch, D.B. (2000) Knowledge, Globalization, and Regions: An economist's perspective. In J.H. Dunning (ed.) Regions, Globalization, and the Knowledge-Based Economy, 63-81, Oxford: Oxford University Press.

Audretsch, D.B. and Feldman, M.P. (1996) R\&D spillovers and the geography of innovation and production, American Economic Review, 86: 630-640.

Audretsch, D.B. and Keilbach, M. (2008) Resolving the knowledge paradox: Knowledge-spillover entrepreneurship and economic growth, Research Policy, 37: 1697-1705.

Audretsch, D.B. and Lehmann, E.E. (2005) Does the Knowledge Spillover Theory of Entrepreneurship hold for regions?, Research Policy, 34: 1191-1202.

Badinger, H. and Tondl, G. (2002) Trade, human capital and innovation: the engines of European regional growth in the 1990s. In Fingleton B. (Ed.) European Regional Growth, pp. 215-240. Springer, Heidelberg.

Barney, J. B. (1991) Firm resources and sustainable competitive advantage, Journal of Management, 17(1): 99-120. 
Bathelt, H. and Glückler, J. (2003) Toward a relational geography, Economic Geography, 3: 117-144.

Bathelt, H. and Schuldt, N. (2008) Between luminaires and meat grinders: International trade fairs as temporary clusters, Regional Studies, 42 (6): 853-868.

Bathelt, H. and Schuldt, N. (2010) International trade fairs and global buzz, Part I: Ecology of global buzz, European Planning Studies, 18 (12), 1957-1974.

Bathelt, $\mathrm{H}$ and Turi, P. (2011) Local, global and virtual buzz: The importance of face-to-face contact in economic interaction and possibilities to go beyond, Geoforum, 42: 520-529.

Bathelt, H. Malmberg, A. and Maskell, P. (2004) Clusters and knowledge: Local buzz, global pipelines and the process of knowledge creation, Progress in Human Geography, 28: 31-56.

Belussi, F. and Sedita, R. (2011) Industrial districts as open learning systems: Combining emergent and deliberate knowledge structures, Regional Studies, DOI:10.1080/00343404.2010.497133.

Benner, C. (2003) Learning communities in a learning region: the soft infrastructure of cross-firm learning networks in Silicon Valley, Environment and Planning A, 35: 1809-1830.

Bergenholtz, C. and Waldstrøm, C. (2011) Inter-organizational network studies: A literature review, Industry and Innovation, 18: 539-562.

Blackler, F. (2002) Knowledge, Knowledge Work, and Organizations. In C.W. Choo and N. Bontis (eds.) The Strategic Management of Intellectual Capital and Organizational Knowledge. New York: Oxford University Press, 47-62.

Bode, E. (2004) The spatial pattern of localized R\&D spillovers: an empirical investigation for Germany, Journal of Economic Geography, 4: 43-64.

Borgatti, S.P. and Foster, P.C. (2003) The network paradigm in organizational research: a review and typology, Journal of Management, 29: 991-1013.

Borts, G. H. and Stein, J. L. (1964) Economic Growth in a Free Market. New York, NY: Columbia University Press.

Boschma, R.A. (2005) Proximity and innovation: A critical assessment, Regional Studies, 39: 61-74.

Boschma R, Frenken K. (2006) Why is economic geography not an evolutionary science? Towards an evolutionary economic geography, Journal of Economic Geography, 6: 273-302.

Boschma, R. and Ter Wal, A. (2007) Knowledge networks and innovative performance in an industrial district: The Case of a footwear district in the South of Italy, Industry and Innovation, 14: 177-199

Boschma, R., Eriksson, R. and Lindgren, U. (2009) How does labour mobility affect the performance of plants? The importance of relatedness and geographical proximity, Journal of Economic Geography, 9: 169-190.

Bourdieu, P. (1986) The forms of capital. In J.G. Richardson (ed.) Handbook of Theory and Research for the Sociology of Education, 241-258, New York: Greenwood.

Brass D.J., Galaskiewicz J., Greve H.R., Tsai W.P. (2004) Taking stock of networks and organizations: A multilevel perspective. Academy of Management Journal, 47: 795-817.

Breschi, S. and Lissoni, F. (2001) Knowledge spillovers and local innovation systems: a critical survey, Industrial and Corporate Change, 10(4): 975-1005.

Breschi, S. and Lissoni, F. (2009) Mobility of skilled workers and co-invention networks: an anatomy of localized knowledge flows, Journal of Economic Geography, 9: 439-468.

Breschi, S. and Malerba F. (2001) The geography of innovation and economic clustering: some introductory notes, Industrial and Corporate Change, 10: 817-34.

Bresnahan, T. and Gambardella, A. (2004) Building High-Tech Clusters: Silicon Valley and Beyond. Cambridge: Cambridge University Press.

Broekel, T. and Boschma, R. (2011) Knowledge networks in the Dutch aviation industry: The proximity paradox, Journal of Economic Geography, Advance Access published May 26, 2011, doi:10.1093/jeg/lbr010.

Brökel, T. and Binder, M. (2007) The regional dimension of knowledge transfers: a behavioral approach, Industry and Innovation, 14: 151-175. 
Burt, R. S. (1992) Structural Holes: The Social Structure of Competition. Cambridge, MA: Harvard University Press.

Callon M. (1999). Le Réseau comme forme émergente et comme modalité de coordination. In M. Callon, P. Cohendet, N. Curien, J.-M. Dalle, F. Eymard-Duvernay, D. Foray and E. Schenk (eds) Réseau et coordination. Paris: Economica, 13-64.

Camagni, R. P. (1991) Local 'milieu', uncertainty and innovation networks: Towards a new dynamic theory of space. In Camagni (Ed.), Innovation networks. London: Belhaven Press.

Cantner, U. Conti, E. and Meder, A. (2009) Networks and innovation: the role of social assets in explaining firms' innovative capacity, Jena Economic Research Papers 2009 - 040, Friedrich Schiller University and the Max Planck Institute of Economics, Jena, Germany.

Cantwell, J. (2005) Innovation and Competitiveness, in Fagerberg, J., Mowery, D.C. and Nelson, R.R. (eds) The Oxford Handbook of Innovation, Oxford: Oxford University Press.

Capello, R. (1999) Spatial transfer of knowledge in high technology milieux: Learning versus collective learning processes. Regional Studies, 33: 353-365.

Capello, R. (2002) Spatial and sectoral characteristics of relational capital in innovation activity, European Planning Studies, 10 (2): 177-200.

Capello, R. and Faggian, A. (2005) Collective learning and relational capital in local innovation processes, Regional Studies, 39: 75-87.

Capello, R. and Nijkamp, P. (eds) (2009) Handbook of Regional Growth and Development Theories. Cheltenham: Edward Elgar.

Castells, M. and Hall, P. (1994) Technopoles of the World: The Making of the Twenty-First Century Industrial Complexes. London: Routledge.

Charlot, S. and Duranton, G. (2004) Communication externalities in cities, Journal of Urban Economics, 56: 581-613.

Charlot, S. and Duranton, G. (2006) Cities and workplace communication: Some quantitative French evidence, Urban Studies, 43 (8): 1365-1394.

Chesbrough, H. (2003) Open Innovation: The New Imperative for Creating and Profiting from Technology. Boston, MA: Harvard Business School Press.

Coe, N, Dicken, P. and Hess, M. (2008) Global production networks: realizing the potential, Journal of Economic Geography, 8 (3): 271-295.

Cohen, W.M. and Levinthal, D.A. (1990) Absorptive capacity: a new perspective on learning and innovation, Administrative Science Quarterly, 35: 128-152.

Coleman, J.S. (1990) Foundations of Social Theory. Cambridge MA and London UK: Belknap:.

Colombo, M., Laursen,K., Magnusson, M. and Rossi-Lamastra, C. (2011):Organizing inter- and intrafirm networks: What is the impact on innovation performance?, Industry and Innovation, 18: 531-538.

Cooke, P. (2004) Regional innovation systems - an evolutionary approach. In Regional innovation systems: The role of governance in a globalised world, (ed.) P. Cooke, M. Heidenreich and H. Braczyk, (1-18). London: Routledge.

Cooke, P. (2009) The economic geography of knowledge flow hierarchies among internationally networked medical bioclusters: A scientometric analysis, Tijdschrift voor Economische en Sociale Geografie, 100: 332-347

Cooke, P. Heidenreich, M. and Braczyk, H. (eds.) (2004) Regional Innovation Systems: The role of Governance in a Globalised World. London: Routledge.

Cooke, P., Asheim, B., Boschma, R., Martin, R., Schwartz, D. and Tödtling, F. (eds) (2011) Handbook of Regional Innovation and Growth, Edward Elgar: Cheltenham.

Courlet, C. and Soulage, B. (1995) Industrial dynamics and territorial space, Entrepreneurship and Regional Development, 7, 285-307.

Cowan R, Jonard N, Zimmerman J-B. (2004) Networks as emergent structures from bilateral collaboration. Maastricht Economic Research Institute on Innovation and Technology: Maastricht. 
Crescenzi R. (2005) Innovation and regional growth in the enlarged Europe: The role of local innovative capabilities, peripherality, and education, Growth and Change, 36: 471-507.

Crevoisier, O. (2004) The innovative milieus approach: Toward a territorialized understanding of the economy?, Economic Geography, 80(4): 367-379.

Crevoisier, O. and Jeannerat, H. (2009) Territorial knowledge dynamics: From the proximity paradigm to multi-location milieus, European Planning Studies, 17 (8): 1223-1241.

Dahlander, L. and Gann, D. M. (2010) How open is innovation? Research Policy, 39 (6): 699-709.

Davenport, S. (2005) Exploring the role of proximity in SME knowledge-acquisition, Research Policy, 34: 683-701.

Dicken, P., Hess, M., Coe, N. and Yeung, H. W-C. (2002) Global production networks and the analysis of economic development, Review of International Political Economy, 9 (3): 436-464.

Doloreux, D. (2004) Regional innovation systems in Canada: a comparative study, Regional Studies, 38: 479-492.

Doloreux, D. and Parto, S. (2005) Regional innovation systems: current discourse and unresolved issues, Technology in Society, 27(2): 133-153.

Döring, T. and Schnellenbach, J. (2006) What do we know about geographical knowledge spillovers and regional growth?: A survey of the literature, Regional Studies, 40: 375-395.

Drejer, I. and Lund Vinding, A. (2007) Searching near and far: determinants of innovative firms' propensity to collaborate across geographical distance, Industry and Innovation, 14: 259275.

Drucker, P. F. (1989) The New Realities: in Government and Politics/In Economics and Business/In Society and World View, New York: Harper and Row.

Dunning, J.H. (2000) Regions, globalization, and the knowledge economy: the issues stated, in J.H. Dunning (ed.) Regions, globalization, and the knowledge-based economy, 7-41, Oxford: Oxford University Press.

Dyer, J.H. and Singh, H. (1998) The relational view: co-operative strategy and sources of interorganizational competitive advantage, Academy of Management Review, 23: 660-79.

Fitjar, R.D. and Rodriguez-Pose, A. (2011) When local interaction does not suffice: sources of firm innovation in urban Norway, Environment and Planning A, 43, 1248-1267.

Fleming, L. King, C. and Juda, A.I. (2007) Small worlds and regional innovation, Organization Science, 18: 938-954.

Florida, R. (2002) The Rise of the Creative Class, New York, NY: Basic Books.

Florida, R. (2005) The world is spiky. Atlantic Monthly, October Issue, 48-51.

Fontes, M. (2005) Distant networking: the knowledge acquisition strategies of 'out-cluster' biotechnology firms, European Planning Studies, 13 (6): 899-920.

Freel M.S. (2000). Do small innovating firms outperform non-innovators? Small Business Economics, 14: $195-210$.

Freeman, C. (1987). Technology, policy, and economic performance: Lessons from Japan, London: Pinter Publishers.

Freeman, C. (1994). The economics of technical change, Cambridge Journal of Economics, 18: 463514.

Frenken, K., van Oort, F.G., Verburg, T. (2007) Related variety, unrelated variety and regional economic growth, Regional Studies, 41, 685-697.

Friedman, T. (2005) The World is Flat: A Brief History of the Globalized World in the $21^{\text {st }}$ Century, London: Allen Lane.

Gargiulo, M. and Benassi, M. (2000) Trapped in your own net? Network cohesion structural holes, and the adaptation of social capital, Organization Science, 11: 183-96.

Garnsey, E. and Heffernan, P. (2005) High-technology clustering through spin-out and attraction: the Cambridge case, Regional Studies, 39: 1127-1144.

Garnsey, E. and Lawton Smith H. (1998) Proximity and complexity in the emergence of high technology industry: the oxbridge comparison, Geoforum, 29: 433-450. 
Garofoli, G. (2002) Local development in Europe: Theoretical models and international comparisons, European Urban and Regional Studies, 9: 225-239.

Gassmann, O. (2006). Opening up the innovation process: towards an agenda. R\&D Management, 36 (3): 223-228.

Gertler, M. and Levitte, Y. (2005). Local nodes in global networks: The geography of knowledge flows in biotechnology innovation, Industry and Innovation, 13:487-507.

Giuliani, E. (2005). Cluster absorptive capacity: Why do some clusters forge ahead and others lag behind? European Urban and Regional Studies, 12: 269-288.

Giuliani, M. and Bell, E. (2005) The micro-determinants of meso-level learning and innovation: Evidence from a Chilean wine cluster, Research Policy, 34: 47-68.

Glaeser, E.L., Kallal, H.D., Scheinkman, J.A. and Shleifer, A. (1992) Growth in cities, Journal of Political Economy 100(6): 1126-1152.

Glückler, J. (2007a) Economic geography and the evolution of networks, Journal of Economic Geography, 7, 619-34.

Glückler, J. (2007b) Geography of reputation: The city as the locus of business opportunity, Regional Studies, 41 (7), 949-961.

Goerzen, A. and Beamish, P. W. (2005) The effect of alliance network diversity on multinational enterprise performance, Strategic Management Journal, 26(4): 333-354.

Goman C.K. (2000) The Human Side of High-Tech: Lessons from the Technology Frontier. New York:John Wiley \& Sons.

Grabher, G. (2001) Ecologies of creativity: the village, the group, and the heterarchic organisation of the British advertising industry, Environment and Planning A, 33(2): 351-374.

Grabher G, and lbert O. (2006). Bad company? The ambiguity of personal knowledge networks, Journal of Economic Geography, 6, 251-271.

Grant R. (1996) Toward a knowledge-based theory of the firm, Strategic Management Journal, 17: 109-122.

Grant, R. and Baden-Fuller. C. (2004) A knowledge accessing theory of strategic alliances, Journal of Management Studies, 41: 61-84.

Griliches, Z. (1979) Issues in Assessing the Contribution of R\&D to Productivity Growth, Bell Journal of Economics, 10: 92-116.

Grossman, G.M. and Helpman, E. (1994) Endogenous innovation in the theory of growth, Journal of Economic Perspectives, 8: 23-44.

Gulati, R. (1999) Network location and learning: the influence of network resources and firm capabilities on alliance formation, Strategic Management Journal, 20: 397-420.

Gulati, R. (2007) Managing Network Resources: Alliances, Affiliations, and Other Relational Assets, Oxford: Oxford University Press.

Gulati, R. and Gargiulo, M. (1999) Where do interorganizational networks come from?, American Journal of Sociology, 104: 1439-1493.

Gulati, R., Nohira, N., and Zaheer, A. (2000) Strategic networks, Strategic Management Journal, 21: 203-215.

Ha, J. and Howitt, P. (2007) Accounting for trends in productivity and R\&D: A schumpeterian critique of semi-endogenous growth theory, Journal of Money, Credit and Banking, 39(4): 733-774.

Harris, R.G. (2001) The knowledge-based economy: Intellectual origins and new economic perspectives, International Journal of Management Reviews, 3: 21-40.

Harris, R.G. (2011) Models of regional growth: Past, present and future, Journal of Economic Surveys, 25: 913-951

Hauser, C. Tappeiner, G. and Walde, J. (2007) The learning region: the impact of social capital and weak ties on innovation, Regional Studies, 41: 75-88.

Hite, J. and Hesterly, W.S. (2001) The evolution of firm networks: from emergence to early growth of the firm, Strategic Management Journal, 22: 275-86. 
Hoekman, J., Frenken, K. and van Oort, F. (2009) The geography of collaborative knowledge production in Europe, Annals of Regional Science, 43: 721-738.

Howells, J. (2012) The geography of knowledge: never so close but never so far apart, Journal of Economic Geography, 12: 1003-1020.

Huber, F. (2011) Do clusters really matter for innovation practices in Information Technology? Questioning the significance of technological knowledge spillovers, Journal of Economic Geography, Advance Access published February 1, 2011, doi:10.1093/jeg/lbq058.

Huggins, R. (1998) Local business co-operation and Training and Enterprise Councils: The development of inter-firm networks, Regional Studies, 32: 813-826.

Huggins, R. (2000) The Business of Networks: Inter-Firm Interaction, Institutional Policy and the TEC Experiment, Aldershot: Ashgate.

Huggins, R. (2001) Inter-firm network policies and firm performance: evaluating the impact of initiatives in the United Kingdom, Research Policy, 30: 443-58.

Huggins, R. (2008) The evolution of knowledge clusters: Progress and policy, Economic Development Quarterly, 22: 277-289.

Huggins, R. (2010) Forms of network resource: Knowledge access and the role of inter-firm networks', International Journal of Management Reviews, 12 (3): 335-352

Huggins, R. and Izushi, H. (2007) Competing for Knowledge: Creating, Connecting and Growing, London: Routledge.

Huggins, R. and Izushi, H. (eds.) (2011) Competition, competitive advantage, and clusters: The ideas of Michael Porter. Oxford: Oxford University Press.

Huggins, R. and Johnston, A. (2010) Knowledge flow and inter-firm networks: The influence of network resources, spatial proximity, and firm size, Entrepreneurship and Regional Development, 22 (5): 457-484.

Huggins, R., Izushi, H., Clifton, N., Jenkins, S., Prokop, D. and Whitfield, C. (2010) Sourcing Knowledge for Innovation: The International Dimension, London: NESTA.

Huggins, R., Thompson, P. and Johnston, A. (2012) Network capital, social capital, and knowledge flow: How the nature of inter-organisational networks impacts on innovation, Industry and Innovation, 19 (3): 203-232.

Ibert, O. (2007) Towards a geography of knowledge creation: The ambivalences between 'knowledge as an object' and 'knowing in practice', Regional Studies, 41: 103-114.

Ireland, R.D. Hitt, M.A. and Vaidyanath. D. (2002) Alliance management as a source of competitive advantage, Journal of Management, 28: 413-46.

Iyer, S. Kitson, M. and Toh, B. (2005) Social capital, economic growth and regional development, Regional Studies, 39: 1015-1040.

Izushi H. (1997) Conflict between two industrial networks: technological adaptation and interfirm relationships in the ceramics industry in Seto, Japan, Regional Studies 31: 117-129.

Jaffe, A. B. (1989) Real effect of academic research, American Economic Review, 79: 957-970.

Jensen, M.B., Johnson, B., Lorenz E. and Lundvall B.-Å. (2007) Forms of knowledge and modes of innovation, Research Policy, 36: 680-693.

Johnson, D.K.N., Siripong, A., Brown, A.S. (2006) The demise of distance? The declining role of physical proximity for knowledge transmission, Growth and Change, 37: 19-33.

Kaldor, N. (1970) The case for regional policies, Scottish Journal of Political Economy, 17: 337-348.

Kale, P. Singh, H. and Perlmutter, H. (2000) Learning and protection of proprietary assets in strategic alliances: building relational capital, Strategic Management Journal, 21(3): 217-237.

Katz, M. L. and Shapiro, C. (1985) Network externalities, competition, and compatibility, American Economic Review, 75 (3): 424-440.

Keller, W. (2002) Trade and the transmission of technology, Journal of Economic Growth, 7(1): 5-24.

Kilduff, M, and Tsai, W. (2003) Social Networks and Organizations, London: Sage.

Kingsley, G., and Malecki, E.J. (2004) Networking for competitiveness, Small Business Economics, 23: 71-84. 
Knoben, J. (2009) Localized inter-organizational linkages, agglomeration effects, and the innovative performance of firms, Annals of Regional Science, 43: 757-779.

Knoben, J. and Oerlemans, L.AG. (2006) Proximity and inter-organizational collaboration, International Journal of Management Reviews, 8: 71-89.

Kodama, F. (1992) Technology Fusion and the New R\&D, Harvard Business Review, (July-August), 7078.

Kogut, B. (2000) The network as knowledge: generative rules and the emergence of structure, Strategic Management Journal, 21: 405-425.

Krackhardt, D. (1994) Constraints on the interactive organization as an ideal type. In Heckscher C. and Donnellon, A. (Eds.) The Post-Bureaucratic Organization: New Perspectives on Organizational Change, Thousand Oaks, CA: Sage.

Kramera, J-P., Marinelli, E. and lammarino, S. and Revilla Diez, J. (2011) Intangible assets as drivers of innovation: Empirical evidence on multinational enterprises in German and UK regional systems of innovation, Technovation, 31 (9): 447-458.

Kramera, J-P. and Revilla Diez, J. (2011) Catching the local buzz by embedding? Empirical insights on the regional embeddedness of multinational enterprises in Germany and the UK, Regional Studies, DOI: 10.1080/00343404.2011.571240.

Krätke, S. (2010) Regional knowledge networks: A network analysis approach to the interlinking of knowledge resources, European Urban and Regional Studies, 17: 83-97.

Labianca, G. and Brass, D.J. (2006) Exploring the social ledger: negative relationships and negative asymmetry in social networks in organizations, Academy of Management Review, 31: 596614.

Lam, A. (2002) Alternative societal models of learning and innovation in the knowledge economy, International Social Science Journal, 54: 67-82.

Lam, A. and Lundvall, B.A. (2006) The learning organisation and national systems of competence building and innovation, in E. Lorenz and B.A. Lundvall (eds.) How Europe's Economies Learn: Coordinating Competing Models, Oxford: Oxford University Press.

Laursen, K., Reichstein, T. and Salter, A. (2011) Exploring the effect of geographical proximity and university quality on university-industry collaboration in the United Kingdom, Regional Studies, 45 (4): 507-523.

Lavie, D. (2006) The competitive advantage of interconnected firms: an extension of the resourcebased view, Academy of Management Review, 31: 638-658.

Lawson, C. and Lorenz, E. (1999) Collective learning, tacit knowledge and regional innovative capacity, Regional Studies, 33: 305-317.

Lawton Smith, H., Romeo, S. and Virahsawmy, M. (2012) Business and professional networks: scope and outcomes in Oxfordshire, Environment and Planning A, 44: $1801-1818$.

Lechner, C. and Dowling, M. (2003) Firm networks: external relationships as sources for the growth and competitiveness of entrepreneurial firms, Entrepreneurship and Regional Development, 15: $1-26$.

Levine, S.S. (2005) The strength of performative ties: three essays on knowledge, social networks, and exchange, PhD dissertation, University of Pennsylvania, PA.

Lichtenthaler, U. (2005) External commercialization of knowledge: review and research agenda, International Journal of Management Reviews, 7: 231-255.

Lissoni, F. (2001) Knowledge codification and the geography of innovation: the case of Brescia mechanical cluster, Research Policy, 30: 1479-1500.

Lorentzen, A. (2008) Knowledge networks in local and global space, Entrepreneurship and Regional Development, 20: 533-545.

Lorenzen, M. (2007) Social capital and localised learning: proximity and place in technological and institutional dynamics, Urban Studies, 44: 799-817.

Lorenzoni, G. and Lipparini, A. (1999) The leverage of interfirm relationships as a distinctive organizational capability: a longitudinal study, Strategic Management Journal, 20: 317-338. 
Lucas R.E. (1988) On the mechanics of economic development, Journal of Monetary Economics, 22, 3-32.

Lundquist, K.-J. and Trippl, M. (2011) Distance, proximity and types of cross-border innovation systems: A conceptual analysis, Regional Studies, DOI:10.1080/00343404.2011.560933

Lundvall, B.-Å. (ed) (1995) National Systems of Innovation: Towards a Theory of Innovation and Interactive Learning. London: Pinter.

Madhavan, R. Koka, B. and Prescott, J.E. (1998) Networks in transition: how industry events (re)shape interfirm relationships, Strategic Management Journal, 19: 439-459.

Maggioni, M. and Uberti, T.E. (2009) Knowledge networks across Europe: which distance matters?, Annals of Regional Science, 43: 691-720.

Maillat, D. (1998a) Innovative milieux and new generations of regional policies, Entrepreneurship and Regional Development, 10: 1-16.

Maillat, D. (1998b) Interactions between urban systems and localized productive systems: An approach to endogenous regional development in terms of innovative milieu, European Planning Studies, 6: 117-129.

Malecki, E.J. (1989) What about people in high technology? Some research and policy considerations, Growth and Change, 20 (1): 67-78.

Malecki, E.J. (2010a) Everywhere? The geography of knowledge, Journal of Regional Science, 50: 493-513.

Malecki, E.J. (2010b) Global knowledge and creativity: New challenges for firms and regions, Regional Studies, 44: 1033-1052.

Malmberg, A. and Maskell, P. (2006) Localized learning revisited, Growth and Change, 37 (1): 1-18.

Malmberg, A. and Power, D. (2006) True clusters: A severe case of conceptual headache. In Asheim, B., Cooke, P. and Martin, R. (eds) Clusters and Regional Development: Critical Reflections and Explorations, Routledge, London.

Mancinelli, S. and Mazzanti, M. (2009) Innovation, networking and complementarity: Evidence on SME performances for a local economic system in North-Eastern Italy, Annals of Regional Science, 43: 567-597.

Marshall, A. (1890) Principles of Economics. London: Macmillan.

Martin, R. (2010) Roepke Lecture in Economic Geography-Rethinking Regional Path Dependence: Beyond Lock-in to Evolution, Economic Geography, 86 (1): 1-27.

Martin, R. and Sunley, P. (2007) Complexity thinking and evolutionary economic geography, Journal of Economic Geography, 7: 573-601.

Maskell, P. (2000) Social capital, innovation, and competitiveness, in Baron, S., Field, J. and Schuller, T. (eds.) Social Capital: Critical Perspectives. Oxford: Oxford University Press.

Maskell, P., Bathelt, H. and Malmberg, A. (2006) Building global knowledge pipelines: The role of temporary clusters, European Planning Studies, 14 (8): 997-1013.

Mattes, J. (2011) Dimensions of proximity and knowledge bases: Innovation between spatial and non-spatial factors, Regional Studies, DOI:10.1080/00343404.2011.552493

Maurer, I. and Ebers, M. (2006) Dynamics of social capital and their performance implications: lessons from biotechnology start-ups, Administrative Science Quarterly, 51: 262-292.

McEvily, B. and Marcus, A. (2005) Embedded ties and the acquisition of competitive capabilities, Strategic Management Journal, 26: 1033-1055.

McEvily, B. and Zaheer. A. (1999) Bridging ties: a source of firm heterogeneity in competitive capabilities, Strategic Management Journal, 20, 1133-1156.

McFadyen, M.A. and Cannella, A.A. (2004) Social capital and knowledge creation: diminishing returns of the number and strength of exchange relationships, Academy of Management Journal, 47: 735-746.

Meagher, K. and Rogers. M. (2004) Network density and R\&D spillovers, Journal of Economic Behavior and Organization 53: 237-260. 
Molina-Morales, F.X. and Martínez-Fernández, M.T. (2009) Too much love in the neighborhood can hurt: how an excess of intensity and trust in relationships may produce negative effects on firms, Strategic Management Journal, 30: 1013-1023.

Monge, P.M., and Contractor, N.S. (2003) Theories of Communication Networks, New York: Oxford University Press.

Moodysson, J. (2008) Principles and practices of knowledge creation: On the organization of "buzz" and "pipelines" in life science communities, Economic Geography, 84 (4): 449-469.

Mowery, D. Oxley, J. and Silverman, B. (1996) Strategic alliances and interfirm knowledge transfer, Strategic Management Journal, 17 (Winter Special Issue): 77-91.

Mueller, P. (2006) Entrepreneurship in the region: Breeding ground for nascent entrepreneurs?, Small Business Economics, 27: 41-58.

Myrdal, G. (1957) Economic Theory and Under-Developed Regions. London: Duckworth.

Nelson RR, Winter SG. (1982) An Evolutionary Theory of Economic Change. Cambridge MA: Belknap Press.

Nonaka I. and Takeuchi. H (1995) The Knowledge-Creating Company: How Japanese Companies Create the Dynamics of Innovation. Oxford: Oxford University Press.

Nooteboom, B. (1999) Inter-Firm Alliances: Analysis and Design. London: Routledge.

Ó hUallacháin, B. and Leslie, T.F. (2007) Rethinking the regional knowledge production function, Journal of Economic Geography, 7, 737-752.

Oliver, C. (1997) Sustainable competitive advantage: combining institutional and resource-based views, Strategic Management Journal, 18: 697-713.

Owen-Smith, J. and Powell, W. W. (2004) Knowledge networks as channels and conduits: the effects of spillovers in the Boston biotechnology community, Organizational Science, 15: 5-21.

Palazzo, G. (2005) Postnational constellations of innovativeness: A cosmopolitan approach, Technology Analysis \& Strategic Management, 17: 55-72.

Penrose, E. (1959/1995) The Theory of the Growth of the Firm. Oxford: Oxford University Press.

Phelps, N.A. (1992) External economies, agglomeration and flexible accumulation, Transactions of the Institute of British Geographers, New Series, Vol. 17 (1): 35-46.

Phelps, N.A. (2004) Clusters, dispersion and the spaces in between: For an economic geography of the banal, Urban Studies, 41 (5-6): 971-989.

Phelps, N.A. and Ozawa, T. (2003) Contrasts in agglomeration: proto-industrial, industrial and postindustrial forms compared, Progress in Human Geography, 27 (5): 583-604.

Podolny, J.M. and Page, K. L. (1998) Network forms of organization, Annual Review of Sociology, 24: 57-76.

Porter, M. E. (1990). The Competitive Advantage of Nations. New York, NY: Free Press.

Porter, M.E. (1998) On Competition, Cambridge, MA: Harvard Business School Press.

Powell, W.W. and Grodal, S. (2005) Networks of innovators. In Fagerberg, J., Mowery, D.C. and Nelson, R.R. (eds) The Oxford Handbook of Innovation, Oxford: Oxford University Press.

Power, D. and Jansson, J. (2008) Cyclical clusters in global circuits: Overlapping spaces in furniture trade fairs, Economic Geography, 84 (4), 423-448.

Prahalad, C. K. and Hamel, G. (1990). The core competence of the corporation, Harvard Business Review, 68(3): 79-91.

Pred, A. R., and Hagerstrand,T. (1967) Innovation Diffusion as a Spatial Process. Chicago: University of Chicago Press.

Putnam, R.D. (2000) Bowling Alone: The Collapse and Revival of American Community. New York: Simon \& Schuster.

Quatraro, F. (2010) Knowledge coherence, variety and economic growth: Manufacturing evidence from Italian regions, Research Policy, 39: 1289-1302.

Rinallo, D. and Golfetto, F. (2011) Exploring the knowledge strategies of temporary cluster organizers: A longitudinal study of the EU fabric industry trade shows (1986-2006), Economic Geography, 87 (4), 453-476. 
Roberts, M. and Setterfield, M. (2010) Endogenous regional growth: A critical survey. In Handbook of Alternative Theories of Economic Growth, ed. M. Setterfield, 431-450. Cheltenham: Edward Elgar.

Rodríguez-Pose, A. and Crescenzi, R. (2008) Research and development, spillovers, innovation systems, and the genesis of regional growth in Europe, Regional Studies, 42, 51-67.

Romer, P. M. (1986) Increasing returns and long-run growth, Journal of Political Economy, 94: 10021037.

Romer, P. M. (1990) Endogenous technological change, Journal of Political Economy, 98: S71-S102.

Romer, P.M. (1996) Why, indeed, in America? Theory, history. and the origins of modern economic growth, American Economic Review, 86: 202-206.

Romer, P.M. (2007) Economic growth. In D. Henderson (ed), The Concise Encyclopedia of Economics. Indianapolis: Liberty Fund.

Rutten, R. and Boekema, F. (eds.) (2007) The Learning Region: Foundations, State of the Art, Future. Cheltenham: Edward Elgar.

Rutten, R. Westlund, H. and Boekema, F. (2010) The spatial dimension of social capital, European Planning Studies, 18: 863-871.

Sammarra, A. and Biggiero, L. (2008) Heterogeneity and specificity of inter-firm knowledge flows in innovation networks, Journal of Management Studies, 45: 800-829.

Saxenian, A. (1994). Regional Advantage: Culture and Competition in Silicon Valley and Route 128. Cambridge, Massachusetts: Harvard University Press.

Saxenian, A. (2005) From brain drain to brain circulation: transnational communities and regional upgrading in India and China, Studies in Comparative International Development, 40, 35-61.

Saxenian, A (2006) The New Argonauts: Regional Advantage in a Global Economy, Cambridge, MA: Harvard University Press.

Schuldt, N. and Bathelt, H. (2011) International trade fairs and global buzz. Part II: Practices of global buzz, European Planning Studies, 19 (1): 1-22.

Schumpeter J.A. (1934) The Theory of Economic Development. Cambridge MA: Harvard University Press.

Brown, J. S. and Duguid, P. (2001) Knowledge and organization: a social practice perspective, Organizational Science, 12: 198-213.

Simmie, J. (2004) Innovation and clustering in the globalised international economy, Urban Studies, 41: 1095-1112.

Simard, C. and West, J. (2006). Knowledge networks and the geographic locus of innovation, in Chesbrough, H., Vanhaverbeke, W. and West, J. (Eds) Open Innovation: Researching a New Paradigm. Oxford University Press, Oxford.

Singh J. (2005) Collaborative networks as determinants of knowledge diffusion patterns, Management Science, 51: 756-770.

Solow, R. (1956) A contribution to the theory of economic growth, Quarterly Journal of Economics, 70: 65-94.

Solow, R. M. (1957) Technical change and the aggregate production function, Review of Economics and Statistics, 39: 312-320.

Stimson, R., Stough, R.R. and Nijkamp, P. (eds) (2011) Endogenous Regional Development: Perspectives, Measurement and Empirical Investigation. Cheltenham: Edward Elgar.

Storper, M. (1997) The Regional World: Territorial Development in a Global Economy. New York: Guilford Press.

Storper M. (2000) Globalizsation and knowledge flows: An industrial geographer's perspective. In Regions, Globalization, and the Knowledge-Based Economy, Dunning JH (eds). Oxford: Oxford University Press.

Storper, M. (2009) Roepke Lecture in Economic Geography: Regional Context and Global Trade, Economic Geography, 85: 1-21. 
Storper, M. and Scott, A.J. (2009) Rethinking human capital, creativity and urban growth, Journal of Economic Geography, 9: 147-167.

Storper, M. and Venables, A.J. (2004) Buzz: face-to-face contact and the urban economy, Journal of Economic Geography, 4: 351-370.

Stuart, T.E. (2000) Interorganizational alliances and the performance of firms: a study of growth and innovation rates in a high-technology industry, Strategic Management Journal, 21: 791-811.

Swan, T. W. (1956) Economic growth and capital accumulation, Economic Record, 32, 334-361.

Tappeiner, G., Hauser, C. and Walde, J. (2008) Regional knowledge spillovers: Fact or artifact?, Research Policy, 37: 861-874.

Teece, D. J. (1998) Capturing value from knowledge assets: the new economy, markets for knowhow, and intangible assets, California Management Review, 40: 55-79.

Ter Wal, A. and Boschma, R. (2011) Co-evolution of firms, industries and networks in space, Regional Studies, 45: 919-933.

Thorngren, B. (1970) How do contact systems affect regional development, Environment and Planning A, 2: 409-27

Thrift. N. and Olds K. (1996) Refiguring the economic in economic geography, Progress in Human Geography, 20 (3): 311-337.

Torré, A., (2008) On the role played by temporary geographical proximity in knowledge transmission, Regional Studies, 42 (6): 869-889.

Torré, A. and Rallet, A. (2005) Proximity and localisation, Regional Studies, 39: 47-59.

Tracey, P. and Clark, G.L. (2003) Alliances, networks and competitive strategy: Rethinking clusters of innovation, Growth and Change, 34: 1-16.

Trippl, M. Tödtling, F. and Lengauer, L. (2009) Knowledge sourcing beyond buzz and pipelines: Evidence from the Vienna software sector, Economic Geography, 85: 443-462.

Tura, T. and Harmaakorpi, V. (2005) Social capital in building regional innovation capability, Regional Studies, 39: 1111-1125.

Van den Bosch, F.A.J., Volberda, H.W. and de Boer, M. (1999). Co-evolution of firm absorptive capacity and knowledge environment: Organizational forms and combinative capabilities, Organization Science 10: 551-568.

van Geenhuizen, M. (2008) Knowledge networks of young innovators in the urban economy: biotechnology as a case study, Entrepreneurship \& Regional Development, 20(2): 161-183.

Vaz, T.D. and Nijkamp, P. (2009) Knowledge and innovation: The strings between global and local dimensions of sustainable growth, Entrepreneurship and Regional Development, 21: 441455.

Vázquez-Barquero, A. (2007) Endogenous development: Analytical and policy issues . In Scott A.J. and Garofoli G. (Eds) Development on the Ground: Clusters, Networks and Regions in Emerging Economies, pp. 23-43, London: Routledge.

von Hippel, E. (1994) 'Sticky information' and the locus of problem solving: Implications for innovation, Management Science, 40 (4): 429-439.

von Hippel, E. (1998) Economics of product development by users: The impact of 'sticky' local information, Management Science, 44 (5): 629-644.

von Hippel, E. (2005) Democratizing innovation. Cambridge, MA: MIT Press.

Vorley, T., Mould, O. and Courtney, R. (2012) My networking is not working! Conceptualizing the latent and dysfunctional dimensions of the network paradigm, Economic Geography, 88 (1):77-96.

Walter, J. Lechner, C. and Kellermanns. F.W. (2007) Knowledge transfer between and within alliance partners: private versus collective benefits of social capital, Journal of Business Research, 60: 698-710.

Watts, H.D. Wood, A.M. and Wardle, P. (2006) Owner-managers, clusters and local embeddedness: Small firms in the Sheffield (UK) metal-working cluster, Entrepreneurship and Regional Development, 18: 185-205. 
Weber M. (1968) On Charisma and Institution Building. Chicago: University of Chicago Press.

Westlund, H. (1999) An interaction-cost perspective on networks and territory, Annals of Regional Science, 33: 93-121

Westlund, H. and Bolton, R. (2003) Local social capital and entrepreneurship, Small Business Economics, 21: 77-113.

Westlund, H. and Nilsson, E. (2005) Measuring enterprises' investments in social capital: a pilot study, Regional Studies, 39: 1079-1094.

Weterings, A. and Ponds, R. (2009) Do regional and non-regional knowledge flows differ? An empirical study on clustered firms in the Dutch life sciences and computing services industry, Industry and Innovation,16: 11-31.

Williamson, O. E. (1993) Calculativeness, trust, and economic organization, Journal of Law and Economics, 36: 453-486.

Wolfe, D. and Gertler, M. (2004) Clusters from the inside and out: local dynamics and global linkages, Urban Studies, 41: 1071-1093.

Yeung, H.W.-C. (2000) Organizing 'the firm' in industrial geography I: networks, institutions and regional development, Progress in Human Geography, 24 (2), 301-315.

Yeung, H.W.-C. (2005) Rethinking relational economic geography, Transactions of the Institute of British Geographers, 30: 37-51.

Zaheer, A. and Bell, G. (2005) Benefiting from network position: firm capabilities, structural holes, and performance, Strategic Management Journal, 26: 809-825.

Zahra, S. A. and George, G. (2002) Absorptive capacity: a review, reconceptualization, and extension. 'Academy of Management Review, 27: 185-203.

Zucker, L.G., Darby, M.R., Furner, J., Liu, R.C. and Hongyan, M. (2007) Minerva unbound: Knowledge stocks, knowledge flows and new knowledge production, Research Policy, 36: 850-863. 
Figure 1: Intra-regional network connections

Density

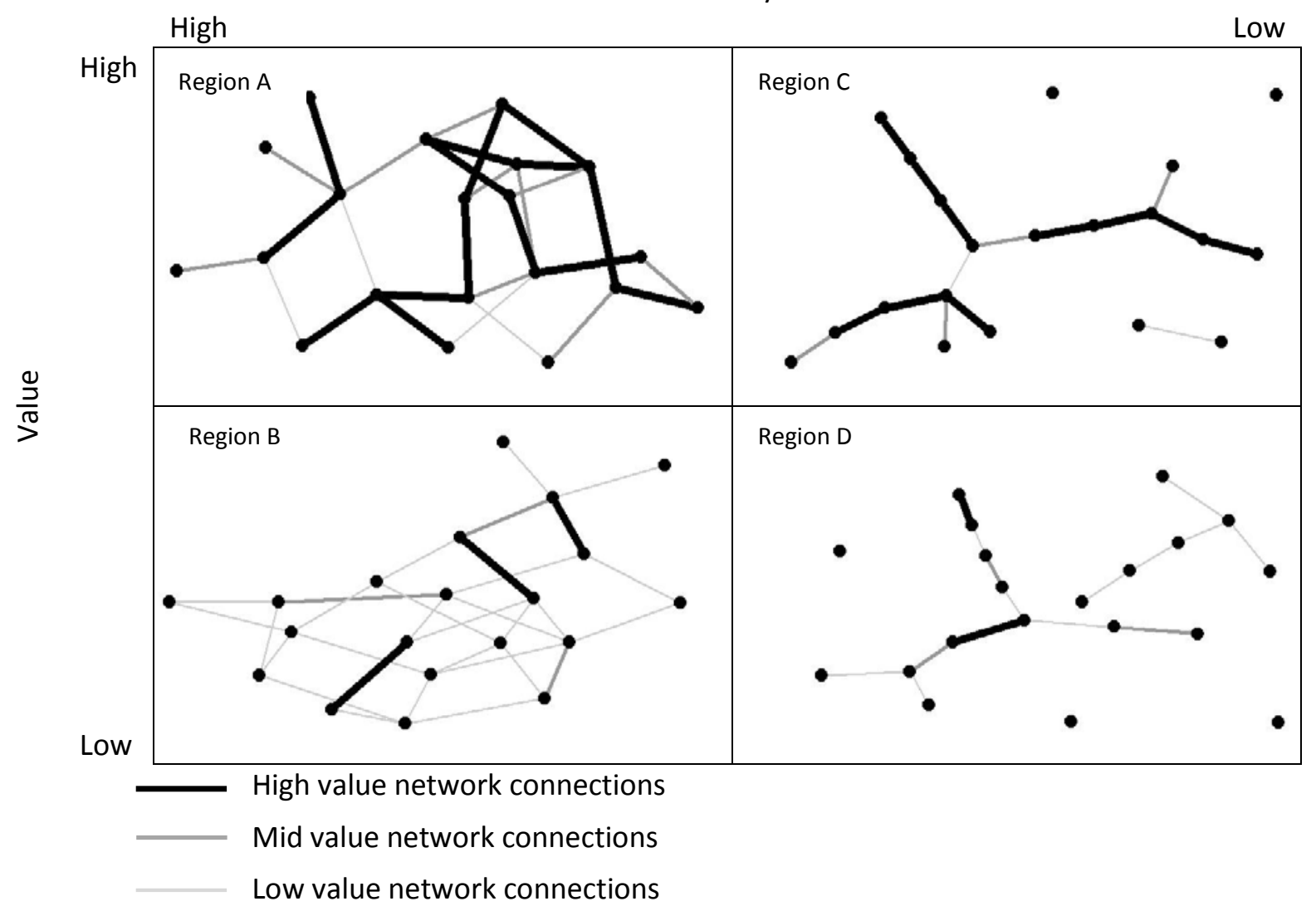


Figure 2: Intra- and Inter-regional network connections

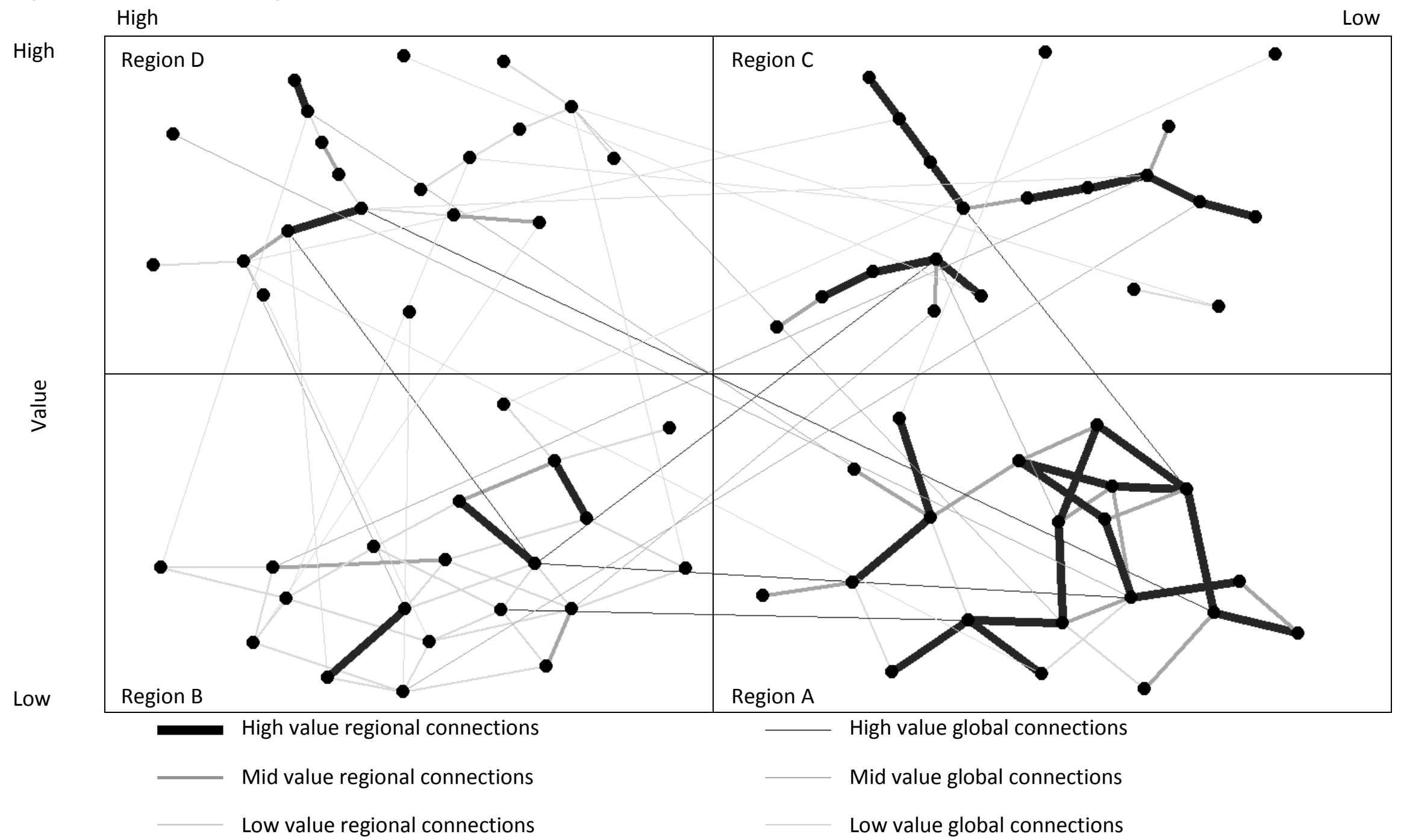


Figure 3: Network Capital and Regional Growth Trajectories

\section{Regional Growth}

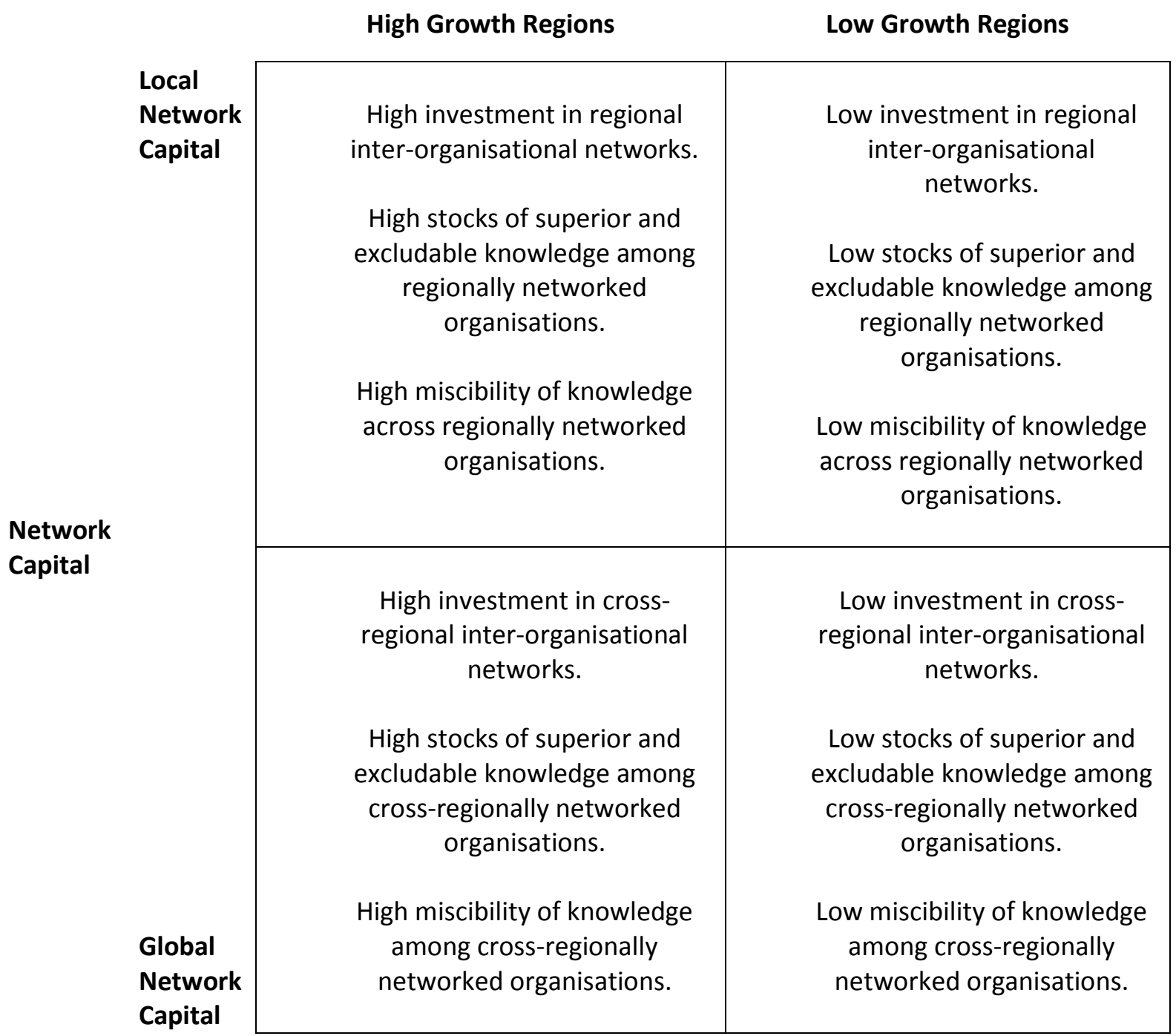

